\title{
Ecophysiology of the kleptoplastidic dinoflagellate Shimiella gracilenta: I. spatiotemporal distribution in Korean coastal waters and growth and ingestion rates
}

\author{
Jin Hee $\mathrm{Ok}^{1}$, Hae Jin Jeong ${ }^{1,2, *}$, Hee Chang Kang ${ }^{1}$, Sang Ah Park ${ }^{1}$, Se Hee Eom ${ }^{1}$, Ji Hyun \\ You $^{1}$ and Sung Yeon Lee ${ }^{1}$
}

${ }^{1}$ School of Earth and Environmental Sciences, College of Natural Sciences, Seoul National University, Seoul 08826, Korea ${ }^{2}$ Research Institute of Oceanography, Seoul National University, Seoul 08826, Korea

To explore the ecophysiological characteristics of the kleptoplastidic dinoflagellate Shimiella gracilenta, we determined its spatiotemporal distribution in Korean coastal waters and growth and ingestion rates as a function of prey concentration. The abundance of S. gracilenta at 28 stations from 2015 to 2018 was measured using quantitative realtime polymerase chain reaction. Cells of $S$. gracilenta were detected at least once at all the stations and in each season, when temperature and salinity were $1.7-26.4^{\circ} \mathrm{C}$ and 9.9-35.6, respectively. Moreover, among the 28 potential prey species tested, S. gracilenta SGJH1904 fed on diverse prey taxa. However, the highest abundance of S. gracilenta was only 3 cells $\mathrm{mL}^{-1}$ during the study period. The threshold Teleaulax amphioxeia concentration for S. gracilenta growth was 5,618 cells $\mathrm{mL}^{-1}$, which was much higher than the highest abundance of T. amphioxeia (667 cells $\mathrm{mL}^{-1}$ ). Thus, T. amphioxeia was not likely to support the growth of S. gracilenta in the field during the study period. However, the maximum specific growth and ingestion rates of $S$. gracilenta on T. amphioxeia, the optimal prey species, were $1.36 \mathrm{~d}^{-1}$ and $0.04 \mathrm{ng} C$ predator $^{-1} \mathrm{~d}^{-1}$, respectively. Thus, if the abundance of $T$. amphioxeia was much higher than $5,618 \mathrm{cells}_{\mathrm{mL}}^{-1}$, the abundance of $S$. gracilenta could be much higher than the highest abundance observed in this study. Eurythermal and euryhaline characteristics of S. gracilenta and its ability to feed on diverse prey species and conduct kleptoplastidy are likely to be responsible for its common spatiotemporal distribution.

Key Words: abundance; feeding; Gymnodinium gracilentum; Kareniaceae; protist; qPCR

\section{INTRODUCTION}

Dinoflagellates are one of the major eukaryotic microorganism groups in marine ecosystems and are ubiquitously present from the equator to the polar (Taylor et al. 2008, Jeong et al. 2021a). They have three major trophic modes: autotrophy, mixotrophy, and heterotrophy (Hansen 1991b, Schnepf and Elbrächter 1992, Jeong et al. 2010a, Stoecker et al. 2017). Thus, they play diverse eco- logical roles, such as primary producers, prey, predators, symbionts, and parasites (Hansen 1991a, Coats 1999, Stat et al. 2008, Jeong et al. 2010b, Fraga et al. 2012, You et al. 2020). They often dominate protist assemblages and cause red tides or harmful algal blooms (Hallegraeff 1993, Smayda and Reynolds 2003, Jeong et al. 2013, Ok et al. 2021b). Furthermore, phototrophic (autotrophic and
(1) \$ This is an Open Access article distributed under the terms of the Creative Commons Attribution Non-Commercial License (http://creativecommons.org/licenses/by-nc/3.0/) which permits unrestricted non-commercial use, distribution, and reproduction in any medium, provided the original work is properly cited.
Received September 17, 2021, Accepted November 28, 2021

*Corresponding Author

E-mail: hjjeong@snu.ac.kr

Tel: +82-2-880-6746, Fax: +82-2-874-9695 
mixotrophic) dinoflagellates are known to have the largest portion of the annual integrated carbon retention of plankton in Masan Bay, Korea (Jeong et al. 2021b). Therefore, to understand the structure and function of marine ecosystems, the distribution of dinoflagellates in the sea and their ecological roles should be explored.

To predict the distribution of dinoflagellates in the sea, its abundance in different regions and environmental factors affecting the abundance should be determined (Bockstahler and Coats 1993, Li et al. 2000, Jeong et al. 2015, Hernández-Becerril et al. 2018, Lee et al. 2019a, 2019b, Ok et al. 2019, Kang et al. 2020). The distribution of dinoflagellates is affected by diverse abiotic factors, such as water temperature, salinity, and nutrient concentrations (Drira et al. 2008, Cohu et al. 2011, Kang et al. 2019, Lee et al. 2021). Furthermore, biotic factors, such as the abundance of prey, predators, and competitors, affect the distribution of dinoflagellates (Tillmann and Reckermann 2002, Matsubara et al. 2007, Jeong et al. 2015). The distribution of autotrophic dinoflagellates is known to be primarily affected by light, nutrient concentrations, water temperature, and predators (Booth and Smith 1997, Gímez et al. 2011, Jeong et al. 2015, Golubkov et al. 2019), whereas that of heterotrophic dinoflagellates is affected by prey and predators (Verity et al. 1993, Jeong 1999, Jeong et al. 2010b, Kim et al. 2013). The distributions of mixotrophic dinoflagellates are mainly affected by prey, light, nutrient concentrations, water temperature, and predators (Bockstahler and Coats 1993, Smalley and Coats 2002, Baek et al. 2008a, 2008b, Jeong et al. 2013, 2015, Yoo et al. 2013, Ok et al. 2017, Golubkov et al. 2019, Jang and Jeong 2020, Eom et al. 2021). Some heterotrophic dinoflagellates conduct photosynthesis using the plastids of ingested prey and are called kleptoplastidic dinoflagellates (Larsen 1988, Schnepf 1992, Schnepf and Elbrächter 1992, 1999, Skovgaard 1998, Gast et al. 2007, Raven et al. 2009, Johnson 2011, Hehenberger et al. 2019). Previous studies have investigated the distribution of only a few kleptoplastidic dinoflagellates such as Dinophysis spp., Pfiesteria piscicida, and Gymnodinium smaydae (Jeong et al. 2006, Lin et al. 2006, Díaz et al. 2011, Lee et al. 2020). However, the distribution of more kleptoplastidic dinoflagellates, environmental factors affecting their distributions, and eco-evolutionary strategies need to be investigated.

Recently, a kleptoplastidic dinoflagellate, Shimiella gracilenta, has been described (Ok et al. 2021a). This dinoflagellate was originally named Gymnodinium gracilentum until recently established as $S$. gracilenta based on molecular and electron microscopic analyses (Camp- bell 1973, Ok et al. 2021a). To date, some ecophysiological characteristics of $S$. gracilenta have been investigated (Skovgaard 1998, Jakobsen et al. 2000, Park et al. 2021); light provided positive effects on the growth and ingestion of S. gracilenta under food-repleted conditions using kleptoplastids and enhanced the survival of $S$. gracilenta under food-depleted conditions (Skovgaard 1998); moreover, the growth rate of $S$. gracilenta was saturated at a light intensity of 60-80 $\mu \mathrm{mol}$ photons $\mathrm{m}^{-2} \mathrm{~s}^{-1}$ (Jakobsen et al. 2000). Interactions between S. gracilenta and heterotrophic protists have been recently explored. Shimiella gracilenta has only a few heterotrophic protistan predators but supports moderate growth rates of the predators (Park et al. 2021). However, spatial and temporal distributions of S. gracilenta, abiotic and biotic factors affecting the distribution, and the numerical and functional responses of $S$. gracilenta to prey concentration have not yet been explored.

Cells of $S$. gracilenta are $<13 \mu \mathrm{m}$ in length and fragile due to lack of theca (Ok et al. 2021a). Some dinoflagellates belonging to Gymnodiniales (e.g., Gymnodinium minutulum and Gymnodinium octo) are morphologically similar to S. gracilenta (Campbell 1973, Larsen 1994), making it difficult to distinguish S. gracilenta from other dinoflagellate species in fixed samples under light microscopes. Thus, to quantify the abundance of S. gracilen$t a$, molecular techniques such as quantitative real-time polymerase chain reaction (qPCR) should be used.

In the present study, the abundance of $S$. gracilenta was quantified at 28 coastal stations along the Korean Peninsula and Jeju Island during four seasons from April 2015 to October 2018, using a qPCR with a newly developed primer-probe set of $S$. gracilenta. Seawaters from the 28 stations have a wide range of water temperatures, salinities, and nutrient concentrations due to the temperate climate and freshwater input from large rivers (Kang et al. 2019, Lee et al. 2019b). Thus, these stations are ideal regions for exploring the environmental factors affecting the distribution of $S$. gracilenta. Correlations between the abundance of S. gracilenta and water temperature, salinity, dissolved oxygen (DO), and the concentrations of nutrients and chlorophyll- $a(\mathrm{Chl}-a$ ) were explored. Furthermore, to investigate the effects of biotic factors on the distribution of S. gracilenta, the prey species that S. gracilenta is able to feed on and growth and ingestion rates of $S$. gracilenta on suitable prey species as a function of prey concentration were determined. Using the data on the abundance of prey species in the literature (Jang and Jeong 2020) and the data on the abundance of S. gracilenta in the present study, the correlations between the 


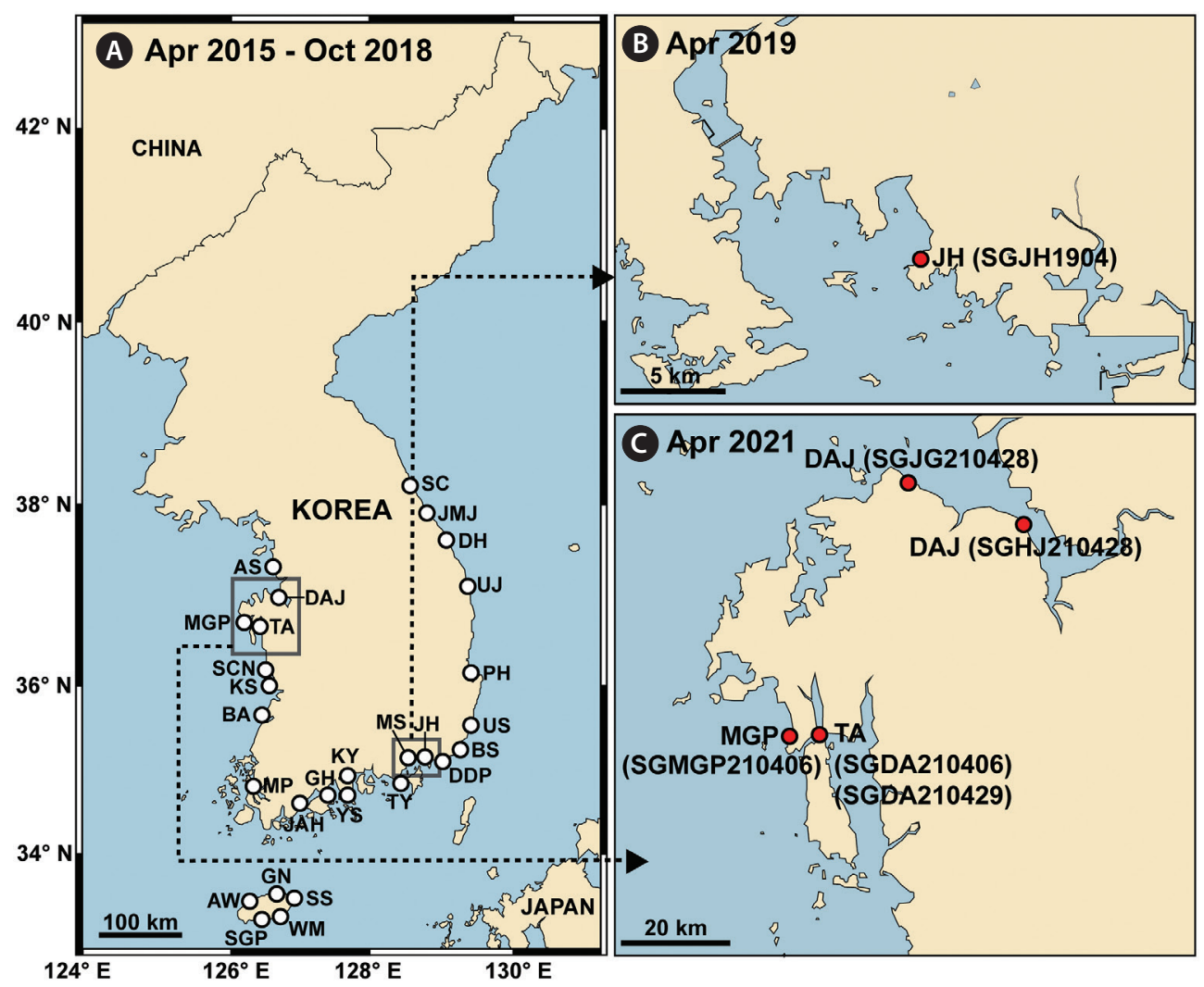

Fig. 1. Map showing the study area. (A) The sampling stations for quantitative real-time polymerase chain reaction during April 2015-October 2018. (B) A site where Shimiella gracilenta was isolated in South Sea of Korea in April 2019. (C) Sites where S. gracilenta was isolated in West Sea of Korea in April 2021. Names in parenthesis represent the strain names of S. gracilenta. SC, Sokcho; JMJ, Jumunjin; DH, Donghae; UJ, Uljin; PH, Pohang; US, Ulsan; BS, Busan; DDP, Dadaepo; MS, Masan; JH, Jinhae; TY, Tongyoung; YS, Yeosu; KY, Kwangyang; GH, Goheung; JAH, Jangheung; AS, Ansan; DAJ, Dangjin; MGP, Mageompo; TA, Taean; SCN, Seocheon; KS, Kunsan; BA, Buan; MP, Mokpo; AW, Aewol; SGP, Seogwipo; WM, Wimi; SS, Seongsan; GN, Gimnyeong.

abundance of $S$. gracilenta and each prey species were explored. The results of the present study provide a basis for understanding the distribution of kleptoplastidic dinoflagellates and biotic and abiotic environmental factors affecting their distribution.

\section{MATERIALS AND METHODS}

\section{Field sample collection during 2015-2018}

Surface water samples were collected from 28 stations along the Korean Peninsula (East, West, and South Seas) and Jeju Island during 2015-2018 (Fig. 1A). These samples were collected seasonally between April 2015 and October 2018 (Supplementary Table S1).

Data on the water temperature, salinity, DO, Chl- $a$ concentration, and the concentration of nitrite plus nitrate $\left(\mathrm{NO}_{2}+\mathrm{NO}_{3}\right.$, hereafter $\left.\mathrm{NO}_{3}\right)$, phosphate $\left(\mathrm{PO}_{4}\right)$, and silicate $\left(\mathrm{SiO}_{2}\right)$ of seawater at 28 stations during the study period were obtained from our previous studies (Kang et al. 2019, Lee et al. 2019b).

For qPCR analysis, $40-600 \mathrm{~mL}$ of seawater was filtered through 25-mm GF/C filters (Whatman Inc., Clifton, NJ, USA). The filtered membrane was stored in a $2.0-\mathrm{mL}$ tube and frozen at $-20^{\circ} \mathrm{C}$ until transfer to the laboratory. DNA from the filtered membrane was extracted using the AccuPrep Genomic DNA Extraction Kit (Bioneer, Daejeon, Korea).

\section{Culture of Shimiella gracilenta}

Shimiella gracilenta SGJH1904 was isolated from a water sample collected from surface water off Jinhae Bay, Korea, in April 2019, when water temperature and salinity were $14.6^{\circ} \mathrm{C}$ and 33.6, respectively (Fig. 1B) (Ok et al. 2021a). The clonal culture of this dinoflagellate was established using two consecutive single-cell isolations, 
and the cryptophyte Teleaulax amphioxeia was provided as prey every $3-4$ days $\left(30,000-50,000\right.$ cells $\left.\mathrm{mL}^{-1}\right)$. The clonal culture in a $250-\mathrm{mL}$ cell culture flask was placed on a shelf at $20^{\circ} \mathrm{C}$ under a $14: 10 \mathrm{~h}$ light : dark cycle and $20 \mu \mathrm{mol}$ photons $\mathrm{m}^{-2} \mathrm{~s}^{-1}$ of cool white fluorescent light.

\section{Species-specific primer and probe design and specificity analysis}

To develop a species-specific primer and probe set for $S$. gracilenta, the sequences of the internal transcribed spacer region of ribosomal DNA (ITS rDNA) of S. gracilenta SGJH1904 and other dinoflagellate species belonging to the family Kareniaceae and related dinoflagellate species were obtained from GenBank (Supplementary Table S2). These sequences were aligned using MEGA v.4 (Tamura et al. 2007). The unique part of the ITS rDNA sequences for $S$. gracilenta was searched from the alignments to develop the S. gracilenta-specific primers and probe. The primer and probe sequences were analyzed using Primer 3 (Whitehead Institute for Biomedical Research, Cambridge, MA, USA) and Oligo Calc: Oligonucleotide Properties Calculator (Kibbe 2007) to determine the optimal melting temperature and secondary structure, respectively. The primers and probe were synthesized by Bioneer (Table 1). The probe was dual-labeled with the fluorescent dyes FAM and BHQ1 at the $5^{\prime}$ and $3^{\prime}$ ends.

Specificity analysis of the primer and probe sets for $S$. gracilenta was conducted using DNA extracts of $S$. gracilenta SGJH1904, 24 dinoflagellate species in Gymnodiniales, Amphidiniales, Dinophysales, Peridiniales, Suessiales, and Thoracosphaerales and cryptophycean prey $T$. amphioxeia (Supplementary Table S3).

The qPCR reaction mixture contained $1 \mu \mathrm{L}$ of DNA template, $0.2 \mu \mathrm{M}$ of specific forward and reverse primers, $0.15 \mu \mathrm{M}$ of the specific probe, $5 \mu \mathrm{L}$ of qPCRBIO Probe Separate-ROX (Genepole, Gwangmyeong, Korea), and deionized sterilized water (DDW; Bioneer), with a final total volume of $10 \mu \mathrm{L}$. The qPCR assay was performed us- ing the Rotor-Gene Q (Qiagen, Hilden, Germany). The cycling conditions were initialized with a denaturation step at $95^{\circ} \mathrm{C}$ for $3 \mathrm{~min}$, followed by 40 cycles of $10 \mathrm{~s}$ at $95^{\circ} \mathrm{C}$ for $10 \mathrm{~s}$, and $58^{\circ} \mathrm{C}$ for $40 \mathrm{~s}$.

\section{Standard curve construction}

A standard curve for determining the abundance of S. gracilenta was constructed using a qPCR. DNA was extracted from the culture of S. gracilenta SGJH1904 $\left(104,000\right.$ cells $\left.\mathrm{mL}^{-1}\right)$ in the growth phase using the AccuPrep Genomic DNA Extraction Kit (Bioneer), targeting 1, $10,100,1,000,10,000$, and 100,000 S. gracilenta cells. The qPCR assay was conducted using the reaction mixture mentioned above under the following thermal cycling conditions: $95^{\circ} \mathrm{C}$ for $3 \mathrm{~min}$, followed by 45 cycles of $10 \mathrm{~s}$ at $95^{\circ} \mathrm{C}$ for $10 \mathrm{~s}$, and $58^{\circ} \mathrm{C}$ for $40 \mathrm{~s}$.

\section{Quantification using qPCR}

DNA samples extracted from seawater were used as the template. Samples using a DDW as the template in the reaction mixture were used as non-template controls. Samples from S. gracilenta SGJH1904 as a template were used as positive and standard controls. The method and conditions used for qPCR to determine the abundance of S. gracilenta in field samples collected during 2015-2018 were the same as those described in the standard curve construction section.

\section{Confirmation of the presence of Shimiella graci- lenta}

The abundance of $S$. gracilenta, measured using the qPCR method in the present study, was as low as 0.01-3 cells $\mathrm{mL}^{-1}$ at all the stations. Thus, surface water samples were collected from three stations in April 2021 to confirm the presence of $S$. gracilenta cells in the samples (Fig 1C). The aliquots were poured into $50 \mathrm{~mL}$ flasks containing T. amphioxeia or Pyramimonas sp. as prey. The flasks

Table 1. Sequences of the primers and probe for Shimiella gracilenta used in this study

\begin{tabular}{|c|c|c|c|c|c|}
\hline Analysis & Primer region & $\begin{array}{c}\text { Primer / } \\
\text { Probe name }\end{array}$ & Direction & Sequence $\left(5^{\prime}-3^{\prime}\right)$ & Reference \\
\hline \multirow[t]{2}{*}{ PCR } & ITS-LSU rDNA & ITSF2 & Forward & TACGTCCCTGCCCTTTGTAC & Litaker et al. (2003) \\
\hline & & LSU500R & Reverse & СССТCATGGTACTTGTTTGC & Litaker et al. (2003) \\
\hline \multirow[t]{3}{*}{ qPCR } & ITS rDNA & Sgracilenta_F & Forward & ACGCATTCAGTTCACAGGTAC & This study \\
\hline & & Sgracilenta_R & Reverse & AGATTCGGAATCAGAGCAGG & This study \\
\hline & & Sgracilenta_P & & [FAM] TCTGTGTCATACGTTGCTTTGTTGATGGC [BHQ1] & This study \\
\hline
\end{tabular}

ITS, internal transcribed spacer; $L S U$, large subunit; $P C R$, polymerase chain reaction; $q P C R$, quantitative real-time PCR. 
were incubated at $20^{\circ} \mathrm{C}$ under a $14: 10 \mathrm{~h}$ light : dark cycle and $20 \mu \mathrm{mol}$ photons $\mathrm{m}^{-2} \mathrm{~s}^{-1}$ of cool white fluorescent light for 3-4 days. After incubation, the contents of the flasks were distributed to 96-well plate chambers. When cells of a dinoflagellate similar to $S$. gracilenta were observed in each chamber in 96-well plates, single-cell isolations were conducted. Finally, two strains SGDA210406 and SGDA210429 from Taean, a strain SGMGP210406 from Mageompo, and two strains SGJG210428 and SGHJ210428 from Dangjin were established (Fig. 1C). The ITS rDNA sequences of these five strains were analyzed to confirm whether they were identical to S. gracilenta SGJH1904 (GenBank accession No. MN965778).

The 100-200 mL aliquots of the seawater samples were used to quantify the abundance of $S$. gracilenta using qPCR, as described above.

\section{Feeding occurrence and mechanism}

To explore the effects of prey species on the distribution of S. gracilenta, the prey species that $S$. gracilenta is able to feed on were investigated. Twenty-seven microalgal species and Mesodinium rubrum were provided as potential prey items (Supplementary Table S4). All prey species except the haptophyte Phaeocystis antarctica and the photosynthetic ciliate $M$. rubrum were grown in enriched $\mathrm{f} / 2$ or Ll seawater media under the same temperature and light conditions as described above (Guillard and Ryther 1962, Guillard and Hargraves 1993). Mesodinium rubrum cells were grown under the same temperature and light conditions described above, and T. amphioxeia was provided as prey. Cells of P. antarctica were grown at $5^{\circ} \mathrm{C}$ under a $14: 10 \mathrm{~h}$ light : dark cycle and $50 \mu \mathrm{mol}$ photons $\mathrm{m}^{-2} \mathrm{~s}^{-1}$ of cool white fluorescent light in enriched L1 seawater medium. The mean equivalent spherical diameter (ESD) of prey species was obtained from previous studies and literature (Mathot et al. 2000, Jeong et al. 2014, Lee et al. 2016, Lim et al. 2018, Eom et al. 2021). The ESD of Chrysochromulina sp. CSYS1905 and
Apedinella sp. ASGY1807 was calculated in this study.

Experiment 1 was conducted to investigate whether $S$. gracilenta SGJH1904 was able to feed on the target prey species (Table 2). Moreover, the feeding mechanism of $S$. gracilenta with regard to the edible prey species was examined. Dense cultures of $S$. gracilenta growing on $T$. amphioxeia were transferred to $800-\mathrm{mL}$ cell culture flasks containing fresh seawater and T. amphioxeia. When prey cells were not detectable (ND) in the seawater, $5-\mathrm{mL}$ aliquots were removed from the flasks and the cell concentration of S. gracilenta was determined under a compound microscope (BX53; Olympus, Tokyo, Japan).

In this experiment, the initial concentrations of $S$. gracilenta and each target prey species were established by using an autopipette to deliver a predetermined volume of culture to $42-\mathrm{mL}$ polycarbonate (PC) experimental bottles. One 42-mL PC experimental bottle containing mixtures of $S$. gracilenta and a target prey species, one prey-only control bottle, and one S. gracilenta-only control bottle were set up. The PC bottles were filled with freshly filtered seawater, capped, placed on a rotating wheel at $0.9 \mathrm{rpm}(0.00017 \times \mathrm{g})$, and incubated under the same conditions as described above. For P. antarctica, this experiment was conducted at $10^{\circ} \mathrm{C}$ because this prey can grow at low temperatures. After 2, 24, and $48 \mathrm{~h}$ of incubation, a 5-mL aliquot from each bottle was removed and transferred to a 6-well plate chamber. Cells of $S$. gracilenta were tracked to examine physical contact, attack (attempt to capture), and successful capture (ingestion) using a dissecting microscope at a magnification of 10-63× and an inverted microscope at a magnification of 200-1,000× (Axiovert 200M; Carl Zeiss, Göttingen, Germany). Cells of $S$. gracilenta incubated with each target prey species were photographed at a magnification of $1,000 \times$ using an inverted microscope. The feeding mechanism of S. gracilenta on prey species was investigated using a video mounted on an inverted microscope at a magnification of $630-1,000 \times$.

Table 2. Design for feeding experiments

\begin{tabular}{clll}
\hline Expt No. & \multicolumn{1}{c}{ Experimental type } & Initial predator concentration $\left(\right.$ cells $\mathbf{~ m L}^{-1}$ ) & \multicolumn{1}{c}{ Initial prey concentration $\left(\right.$ cells $\mathbf{~ m L}^{-1}$ ) } \\
\hline 1 & Shimiella gracilenta & Approximately 5,000 & See Table 6 \\
2 & S. gracilenta with Teleaulax & $16,70,393,565,1,142,2,948,5,095,9,980$ & $169,888,4,612,7,198,14,522,29,198$, \\
& amphioxeia cells & & $52,086,103,559$ \\
& S. gracilenta with T. amphioxeia & $18,82,411,662,1,336,3,396,5,663,11,638$ & 0 (filtrates corresponding to 169, 888, 4,612, \\
& filtrate & & $7,198,14,522,29,198,52,086,103,559)$ \\
3 & S. gracilenta with f/2 medium & 4,622 & 0 \\
& $\begin{array}{l}\text { S.gracilenta } \text { without any } \\
\text { addition }\end{array}$ & 4,849 & 0 \\
\hline
\end{tabular}




\section{Effects of prey concentration on growth and ingestion rates}

Experiment 2 was conducted to determine the specific growth and ingestion rates of S. gracilenta SGJH1904 as a function of prey concentration (Table 2). Dense cultures of S. gracilenta in a $250-\mathrm{mL}$ flask were transferred to 1,000-mL PC bottles with freshly filtered seawater and $T$. amphioxeia prey (ca. 40,000 cells $\mathrm{mL}^{-1}$ ). A dense culture of T. amphioxeia in a $250-\mathrm{mL}$ flask was transferred to a 1,000-mL PC bottle with f/2 medium. These stock cultures were incubated at $20^{\circ} \mathrm{C}$ under a $14: 10 \mathrm{~h}$ light : dark cycle and $100 \mu \mathrm{mol}$ photons $\mathrm{m}^{-2} \mathrm{~s}^{-1}$ of a light-emitting diode. We selected light intensity above which the maximum growth and ingestion rates of S. gracilenta (G. gracilentum) as a function of light intensity were observed (Jakobsen et al. 2000). Shimiella gracilenta cells were allowed to feed on prey cells for 4 days and then starved for 8 days. A negative growth rate of S. gracilenta $\left(-0.1 \mathrm{~d}^{-1}\right)$ was obtained in this culture, indicating a lack of residual growth of $S$. gracilenta after feeding on prey. Three 1-mL aliquots were removed from the stock cultures, and the concentrations of S. gracilenta and T. amphioxeia were determined.

Eight different initial concentrations of S. gracilenta and T. amphioxeia were established using an autopipette to deliver predetermined volumes into 38 -mL flasks (Table 2). Triplicate flasks with predator-prey mixtures, preyonly controls (i.e., T. amphioxeia only), and predatoronly controls (i.e., S. gracilenta only) were set up for the eight different cell concentrations of $S$. gracilenta and $T$. amphioxeia. The stock culture of the predator S. gracilen$t a$ was filtered through a $0.2-\mu \mathrm{m}$ syringe filter (DISMIC25CS type, $25 \mathrm{~mm}$; Advantec, Toyo Roshi Kaisha Ltd., Chiba, Japan). The same amount of cell-free filtrate was added to the prey-only controls as the predator culture volume was added to the predator-prey mixtures. The stock culture of T. amphioxeia was filtered in the same manner. The same amount of cell-free filtrate was added to the predator-only controls as the prey culture volume was added to the predator-prey mixtures. This procedure ensured that the seawater conditions were similar to those of the predator-prey mixtures to determine the elevated growth rate as a result of predation alone. Five milliliters of $\mathrm{f} / 2$ medium were added to all the flasks that were then filled with freshly filtered seawater.

At the start of the incubation period, a 5-mL aliquot was taken from each flask to determine the actual concentrations of the predator and prey, and then fixed with $5 \%$ Lugol's solution. Next, each flask was refilled to ca- pacity with freshly filtered seawater and placed on a shelf under the above conditions. Dilution due to refilling of filtered seawater into each flask was considered when the growth and ingestion rates were calculated. After a 2-day incubation period, a 10-mL aliquot was taken from each flask and fixed as described above.

Fixed S. gracilenta and T. amphioxeia cells taken at the beginning of the incubation period and after 2 days of incubation were enumerated by counting all or $>200$ cells in 1-mL Sedgwick-Rafter chambers under a compound microscope.

The specific growth rate of $S$. gracilenta $\left(\mu, \mathrm{d}^{-1}\right)$ was calculated using the following equation:

$$
\mu=\frac{\operatorname{Ln}\left(\frac{C_{t}}{C_{0}}\right)}{t}
$$

, where $\mathrm{C}_{0}$ and $\mathrm{C}_{\mathrm{t}}$ represent the concentration of $\mathrm{S}$. gracilenta at the beginning of incubation and after the elapsed time (t) of incubation, respectively.

The results for the growth rate of S. gracilenta with $T$. amphioxeia cells were fitted to the Michaelis-Menten equation using DaltaGraph (SPSS Inc., Chicago, IL, USA):

$$
\mu=\frac{\mu_{\max }\left(x-x^{\prime}\right)}{\mathrm{K}_{\mathrm{GR}}+\left(x-x^{\prime}\right)}
$$

, where $\mu_{\max }$ is the maximum growth rate $\left(\mathrm{d}^{-1}\right), x$ is the concentration of T. amphioxeia prey ( $\left.\mathrm{ng} \mathrm{C} \mathrm{mL}^{-1}\right), x^{\prime}$ is the threshold prey concentration (i.e., prey concentration where $\mu=0$ ), and $\mathrm{K}_{\mathrm{GR}}$ is the prey concentration sustaining half of $\mu_{\max }$.

The ingestion and clearance rates were calculated using the equation of Frost (1972) and the modified equation of Heinbokel (1978). Data for the ingestion rates of $S$. gracilenta (IR; ng C predator ${ }^{-1} \mathrm{~d}^{-1}$ ) were also fitted to the Michaelis-Menten equation:

$$
\mathrm{IR}=\frac{\mathrm{I}_{\max }(x)}{\mathrm{K}_{\mathrm{IR}}+(x)}
$$

, where $\mathrm{I}_{\max }$ is the maximum ingestion rate, and $\mathrm{K}_{\mathrm{IR}}$ is the prey concentration sustaining half of $\mathrm{I}_{\max }$. The carbon content of T. amphioxeia was obtained from Jeong et al. (2005b).

\section{Effects of filtrates of prey culture and $f / 2$ medium on the growth rate}

Experiment 3 was conducted to determine whether filtrates of stock cultures of T. amphioxeia (i.e., without prey cells) or $\mathrm{f} / 2$ medium affected the growth rates of $S$. graci- 
lenta SGJH1904. The growth rates of S. gracilenta with $T$. amphioxeia cells, only $T$. amphioxeia filtrates, only f/2 medium, and without any addition were compared (Table 2). Data on the growth rates of $S$. gracilenta with $T$. amphioxeia cells and without prey cells but filtrates (i.e., predator-only controls) were obtained from the results of experiment 2. For experiments involving the addition of $\mathrm{f} / 2$ medium or no additions, $S$. gracilenta cells were satiated with T. amphioxeia for 14 days, followed by starvation for 26 days. At this point, the growth rate of S. gracilenta was negative $\left(-0.1 \mathrm{~d}^{-1}\right)$. A single high concentration of $S$. gracilenta $\left(5,000\right.$ cells $\left.\mathrm{mL}^{-1}\right)$ was set up in triplicate. The growth rate of $S$. gracilenta was determined as described previously.

\section{Statistical analysis}

Pearson's correlation analysis was used to test the relationships between the abundance of $S$. gracilenta and biotic / abiotic factors. Data on the abundances of T. amphioxeia and Pyramimonas sp. at 28 stations from 2015 to 2018 were obtained from Jang and Jeong (2020). Oneway analysis of variance (ANOVA) with a post-hoc Tukey's honestly significant difference test was used to compare the growth rates of S. gracilenta SGJH1904 with T. amphioxeia cells, only $T$. amphioxeia filtrates, f/2 medium, and without any addition. The normality and homogeneity of the data were tested prior to the one-way ANOVA analysis. Statistical significance was set at $\mathrm{p}<0.05$. All statistical analyses were performed using SPSS ver. 25.0 (IBMSPSS Inc., Armonk, NY, USA).

\section{RESULTS}

\section{Specificity test and standard curve construction}

The species specificity of the primer and probe set developed in this study was tested using $S$. gracilenta SGHJ1904 and the other 25 species (Supplementary Table S3). Shimiella gracilenta was positively detected, whereas the remaining species were negatively detected.

The standard curve indicated high linearity between log cell number and cycle threshold (Ct) with $r^{2}=0.996$ (Supplementary Fig. S1). The slope for $\mathrm{Ct}$ as a function of log cell abundance was -3.18 , which corresponds to an efficiency of $106 \%$.

\section{Spatial distributions in Korean waters}

Using the primer and probe set developed in this study, the abundance of $S$. gracilenta in water samples from 28 stations from April 2015 to October 2018 was quantified (Table 3). Cells of S. gracilenta were detected at all the 28 stations from 2015 to 2018, indicating its wide spatial distribution. However, its cell abundance in Korean coastal waters in 2015 to 2018 was very low (Table 3); the highest abundance of $S$. gracilenta $\left(2.96\right.$ cells $\mathrm{mL}^{-1}$ ) was found in Seogwipo (Jeju Island), and the second highest abundance $\left(2.25\right.$ cells $\left.\mathrm{mL}^{-1}\right)$ was in the waters off Ansan.

\section{Temporal distributions in Korean waters}

Cells of S. gracilenta were detected during all four seasons: 18 stations in spring and summer, 16 stations in autumn, and 13 stations in winter (Fig. 2). The highest and second highest abundances of S. gracilenta (2.96 and 2.25 cells $\mathrm{mL}^{-1}$, respectively) were found in the summer of 2016 and 2017, respectively (Table 3, Fig. 2B). In spring, autumn, and winter seasons in 2015 to 2018, the highest abundances of $S$. gracilenta were $<1$ cell $\mathrm{mL}^{-1}$ (Fig. 2A, C \& D): 0.71 cells $\mathrm{mL}^{-1}$ in spring, 0.61 cells $\mathrm{mL}^{-1}$ in autumn, and 0.63 cells $\mathrm{mL}^{-1}$ in winter (Table 3 ).

\section{Hydrographic and biological properties}

Abiotic environmental factors, such as water temperature, salinity, and DO, varied greatly between 2015 and 2018 (Table 4). Cells of S. gracilenta were detected in Korean coastal waters when water temperature, salinity, and DO ranged 1.7-26.4 ${ }^{\circ} \mathrm{C}, 9.9-35.6$, and 0.7-14.2 $\mathrm{mg} \mathrm{L}^{-1}$, respectively (Table 4 ). Furthermore, when $S$. gracilenta was detected, the concentrations of $\mathrm{NO}_{3}, \mathrm{PO}_{4}$, and $\mathrm{SiO}_{2}$ were in between ND-107.1, ND-6.3, and ND-448.4 $\mu \mathrm{M}$, respectively. The highest abundance of S. gracilenta (2.96 cells $\mathrm{mL}^{-1}$ ) was detected when the water temperature and salinity were $20.4^{\circ} \mathrm{C}$ and 17.5 , respectively (Fig. 3A); moreover, this abundance value was observed when $\mathrm{NO}_{3}$ and $\mathrm{PO}_{4}$ concentrations were 43.0 and $0.90 \mu \mathrm{M}$, respectively (Fig. 3B). However, S. gracilenta abundance was significantly correlated with water temperature and salinity, but not with $\mathrm{DO}, \mathrm{NO}_{3}, \mathrm{PO}_{4}$, and $\mathrm{SiO}_{2}$ (Table 4).

Biotic factors such as Chl- $a$ and the abundance of the prey species T. amphioxeia or Pyramimonas sp. from 2015 to 2018 also varied considerably (Table 4). Cells of $S$. gracilenta were detected when Chl- $a$ ranged from 0.2 to $59.1 \mu \mathrm{L} \mathrm{L}^{-1}$. Moreover, S. gracilenta was also detected when the abundances of T. amphioxeia and Pyramimonas sp. 

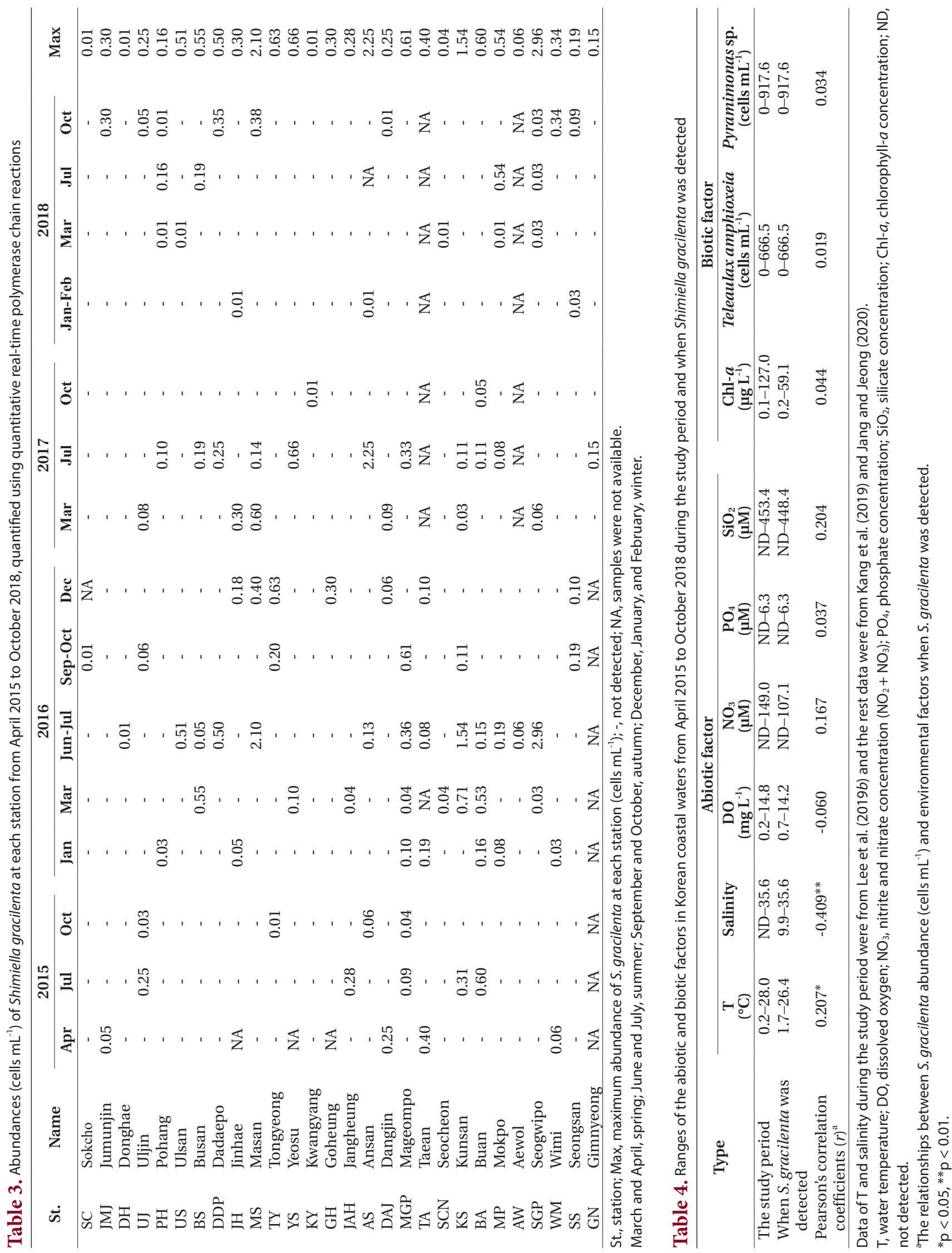

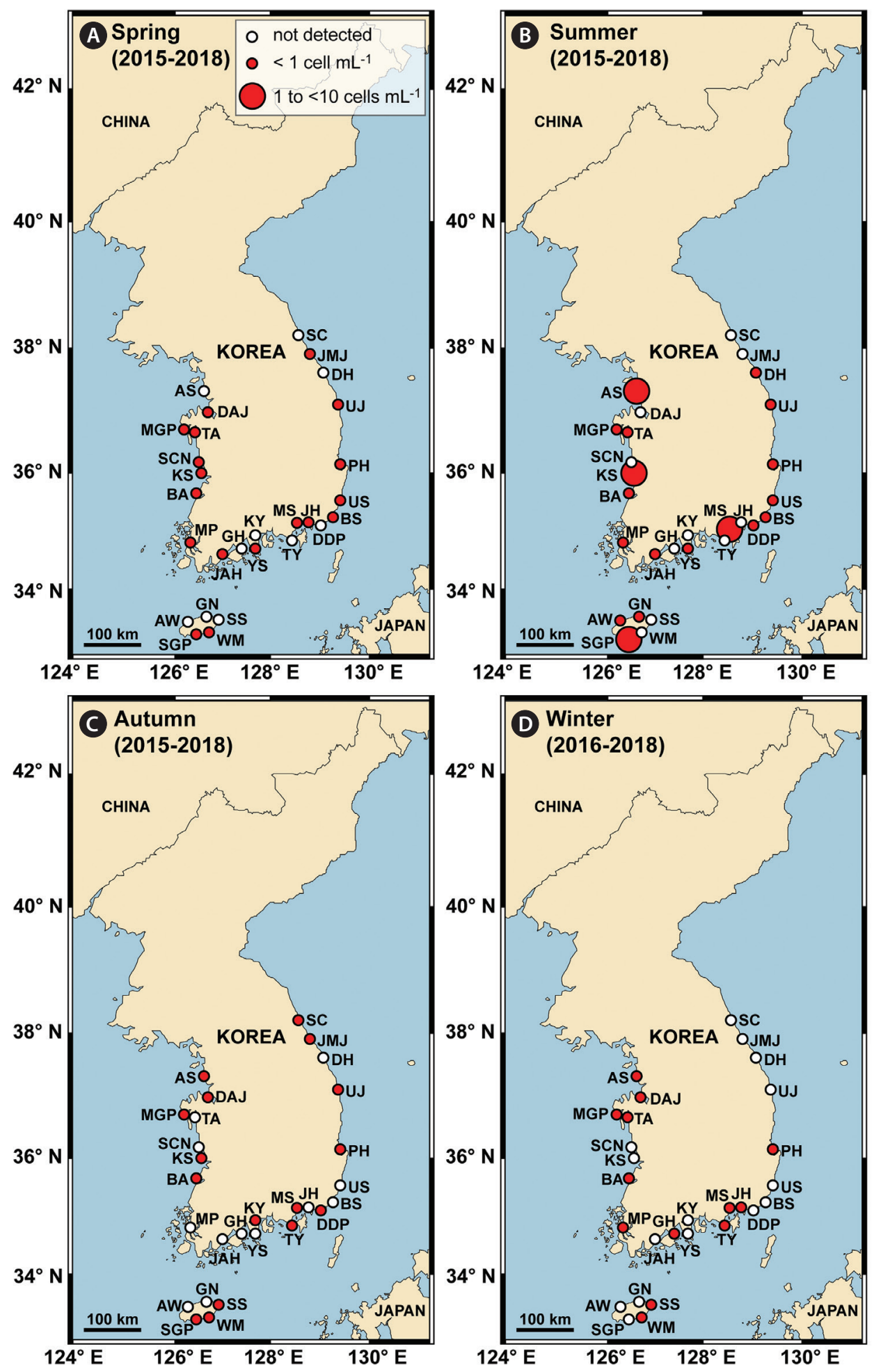

Fig. 2. Map of the sampling stations indicating the presence or absence of Shimiella gracilenta during April 2015-October 2018. (A) Spring (March or April). (B) Summer (June or July). (C) Autumn (September or October). (D) Winter (December, January, or February). The red closed circles indicate the stations where $S$. gracilenta cells were detected, whereas black open circles indicate the stations where $S$. gracilenta cells were not detected. The size of the red closed circles represents the abundance of S. gracilenta cells. SC, Sokcho; JMJ, Jumunjin; DH, Donghae; UJ, Uljin; PH, Pohang; US, Ulsan; BS, Busan; DDP, Dadaepo; MS, Masan; JH, Jinhae; TY, Tongyoung; YS, Yeosu; KY, Kwangyang; GH, Goheung; JAH, Jangheung; AS, Ansan; DAJ, Dangjin; MGP, Mageompo; TA, Taean; SCN, Seocheon; KS, Kunsan; BA, Buan; MP, Mokpo; AW, Aewol; SGP, Seogwipo; WM, Wimi; SS, Seongsan; GN, Gimnyeong. 

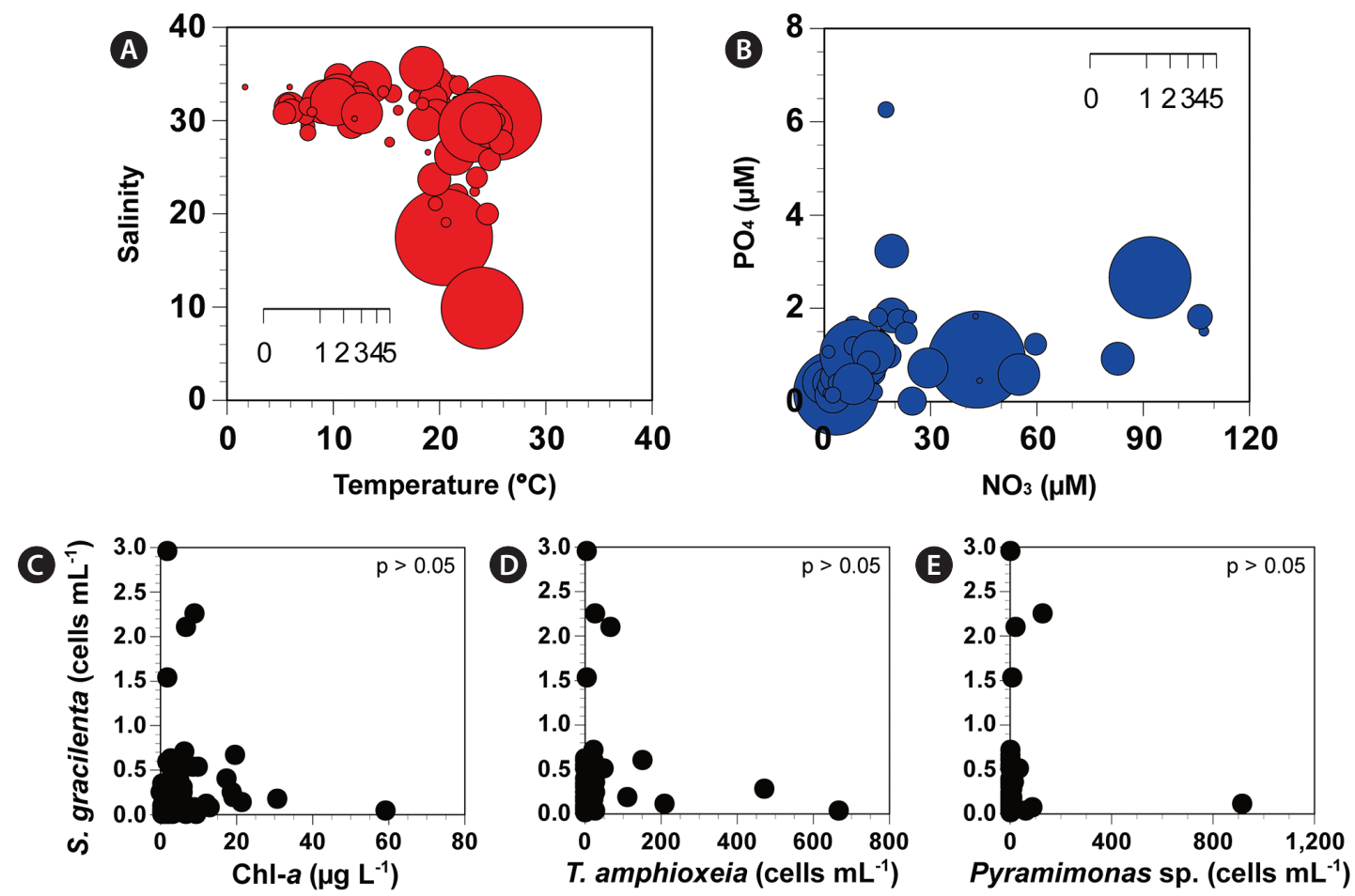

Fig. 3. Abundances (cells $\mathrm{mL}^{-1}$ ) of Shimiella gracilenta as a function of each abiotic / biotic factors at stations where S. gracilenta cells were detected from April 2015 to October 2018. Abundance as a function of water temperature and salinity (A), $\mathrm{NO}_{3}$ and PO $\mathrm{P}_{4}(\mathrm{~B}), \mathrm{Chl}-a(\mathrm{C})$, the abundance of prey Teleaulax amphioxeia (D), and the abundance of prey Pyramimonas sp. (E). Circle diameters in (A) and (B) scaled to the abundance of $S$. gracilenta.

were $0-666.5$ and 0-917.6 cells $\mathrm{mL}^{-1}$, respectively. However, the abundance of $S$. gracilenta was not significantly correlated with Chl- $a$ or abundance of T. amphioxeia or Pyramimonas sp. (Table 4, Fig. 3C-E).

\section{Confirmation on the presence of Shimiella graci- lenta}

The sequences of ITS rDNA of the five $S$. gracilenta strains (SGMGP210406, SGDA210406, SGJG210428, SGHJ 210428 , and SGDA210429) were $100 \%$ identical to that of S. gracilenta SGJH1904 (Table 5).

When the qPCR method was used, the abundance of $S$. gracilenta in the water samples at stations where the cells of the five strains were isolated ranged from 0.31 to 2.94 cells $\mathrm{mL}^{-1}$ (Table 5). The water temperature and salinity when these five strains were isolated ranged $9.6-14.9^{\circ} \mathrm{C}$ and 29.2-31.3, respectively (Table 5).

\section{Prey type}

Among the microalgal and ciliate species that were provided as prey, S. gracilenta SGJH1904 was observed to feed on the prymnesiophytes Chrysochromulina sp. and P.antarctica, the cryptophytes T. amphioxeia, Storeatula major, Rhodomonas salina, the prasinophyte Pyramimonas sp.,

Table 5. Information on Shimiella gracilenta strains collected in April 2021, sequence identity, and their abundance (cells $\mathrm{mL}^{-1}$ ) quantified using qPCR

\begin{tabular}{lllcccc}
\hline \multicolumn{1}{c}{ Strain name } & Collection area & Collection date & T $\left({ }^{\circ} \mathbf{C}\right)$ & Salinity & Sequence identity (\%) & Abundance \\
\hline SGMGP210406 & Mageompo, Korea & Apr 6, 2021 & 9.6 & 31.3 & 100 & 100 \\
SGDA210406 & Taean, Korea & Apr 6, 2021 & 11.0 & 31.3 & 100 & 0.31 \\
SGJG210428 & Dangjin, Korea & Apr 28, 2021 & 12.2 & 30.1 & 100 & 0.81 \\
SGHJ210428 & Dangjin, Korea & Apr 28, 2021 & 13.9 & 29.2 & 1.03 \\
SGDA210429 & Taean, Korea & Apr 29, 2021 & 14.9 & 30.8 & 100 & 2.66 \\
\hline
\end{tabular}

Sequence identity of the five strains against that of S. gracilenta SGJH1904 (GenBank accession No. MN965778) in the internal transcribed spacer ribosomal DNA region was compared using megaBLAST in the NCBI BLAST.

qPCR, quantitative real-time polymerase chain reaction; $T$, water temperature. 
and the dictyochophyte Apedinella sp. (Table 6). The ESD of these prey species were $\leq 8.8 \mu \mathrm{m}$ (Table 6 ). Under a light microscope, yellowish, greenish, or reddish prey materials were observed inside the protoplasm of $S$. gracilenta cells (Fig. 4). However, S. gracilenta cells did not feed on the prymnesiophyte Isochrysis galbana, the chlorophyte Dunaliella salina, the dictyochophyte Pseudopedinella elastica, the raphidophyte Heterosigma akashiwo, the diatom Skeletonema costatum, all the dinoflagellates tested in this study, and the ciliate M. rubrum (Table 6). Among these microalgal and ciliate species, although $S$. gracilenta was found to attack I. galbana and S. costatum, it failed to ingest these two species.

\section{Feeding mechanism}

Shimiella gracilenta SGJH1904 fed on a R. salina cell using a peduncle (Fig. 5). The materials (yellow) were observed to be transported from the prey to the predator through a thin peduncle.

\section{Effects of prey concentration on the growth rate}

With increasing mean prey concentrations, the specific growth rate of S. gracilenta SGJH1904 on T. amphioxeia rapidly increased at mean prey concentrations of $\leq 199 \mathrm{ng}$ $\mathrm{C} \mathrm{mL}^{-1}\left(11,697\right.$ cells $\left.\mathrm{mL}^{-1}\right)$. However, it became saturated

Table 6. Taxa, size, and concentration of algal prey species offered to Shimiella gracilenta SGJH1904, and feeding occurrence

\begin{tabular}{|c|c|c|c|c|c|}
\hline Organisms & Strain name & $\begin{array}{l}\text { ESD } \\
(\mu \mathrm{m})\end{array}$ & $\begin{array}{l}\text { Initial cell density } \\
\quad\left(\text { cells } \mathrm{mL}^{-1}\right)\end{array}$ & Attack & Feeding \\
\hline \multicolumn{6}{|l|}{ Prymnesiophyte } \\
\hline Chrysochromulina sp. & CSYS1905 & 3.1 & 700,000 & ० & o \\
\hline Phaeocystis antarctica & RCC4023 & 3.1 & 500,000 & $\circ$ & $\circ$ \\
\hline Isochrysis galbana & IG & 4.8 & 300,000 & $\circ$ & $x$ \\
\hline \multicolumn{6}{|l|}{ Cryptophyte } \\
\hline Teleaulax amphioxeia & TSGS0202 & 5.6 & 150,000 & $\circ$ & $\circ$ \\
\hline Storeatula major & SSSH1103 & 6.0 & 100,000 & $\circ$ & $\circ$ \\
\hline Rhodomonas salina & $\mathrm{RS}$ & 8.8 & 50,000 & $\circ$ & $\circ$ \\
\hline \multicolumn{6}{|l|}{ Prasinophyte } \\
\hline Pyramimonas sp. & PSSH1204 & 5.6 & 150,000 & $\circ$ & $\circ$ \\
\hline \multicolumn{6}{|l|}{ Chlorophyte } \\
\hline Dunaliella salina & DSJH1710 & 10.3 & 30,000 & $x$ & $x$ \\
\hline \multicolumn{6}{|l|}{ Dictyochophyte } \\
\hline Apedinella sp. & ASGY1807 & 7.0 & 50,000 & $\circ$ & $\circ$ \\
\hline Pseudopedinella elastica & PEJH1904 & 7.9 & 50,000 & $x$ & $x$ \\
\hline \multicolumn{6}{|l|}{ Raphidophyte } \\
\hline Heterosigma akashiwo & HAKS9905 & 11.5 & 30,000 & $x$ & $x$ \\
\hline \multicolumn{6}{|l|}{ Diatom } \\
\hline Skeletonema costatum & SCYS1801 & 5.9 & 150,000 & $\circ$ & $x$ \\
\hline \multicolumn{6}{|l|}{ Dinoflagellate } \\
\hline Heterocapsa rotundata & HRSH1201 & 5.8 & 50,000 & $x$ & $x$ \\
\hline Amphidinium carterae & SIO PY-1 & 9.7 & 30,000 & $x$ & $x$ \\
\hline Effrenium voratum & SvFL 1 & 11.1 & 30,000 & $x$ & $x$ \\
\hline Prorocentrum cordatum & PMKS9906 & 12.1 & 15,000 & $x$ & $x$ \\
\hline Karlodinium veneficum & KVJH1607 & 12.5 & 30,000 & $x$ & $x$ \\
\hline Heterocapsa steinii & HTMS0806 & 15.0 & 15,000 & $x$ & $x$ \\
\hline Alexandrium minutum & CCMP1888 & 20.4 & 10,000 & $x$ & $x$ \\
\hline Karenia mikimotoi & NIES-2411 & 21.3 & 3,000 & $x$ & $x$ \\
\hline Scrippsiella acuminata & STGP9909 & 22.8 & 10,000 & $x$ & $x$ \\
\hline Margalefidinium polykrikoides & CPWD1509 & 25.9 & 3,000 & $x$ & $x$ \\
\hline Prorocentrum micans & PMSH0910 & 26.6 & 3,000 & $x$ & $x$ \\
\hline Akashiwo sanguinea & ASUSA & 30.8 & 1,000 & $x$ & $x$ \\
\hline Tripos furca & TFDD1808 & 28.9 & 2,000 & $x$ & $x$ \\
\hline Alexandrium fraterculus & AFYS1309 & 32.3 & 2,000 & $x$ & $x$ \\
\hline Lingulodinium polyedra & CCMP1931 & 38.2 & 1,500 & $x$ & $x$ \\
\hline \multicolumn{6}{|l|}{ Ciliate } \\
\hline Mesodinium rubrum & MR-MAL01 & 22.0 & 2,000 & $x$ & $x$ \\
\hline
\end{tabular}

ESD, equivalent spherical diameter; 0 , attacked or fed by S. gracilenta; $\times$, not attacked or fed by S. gracilenta. 

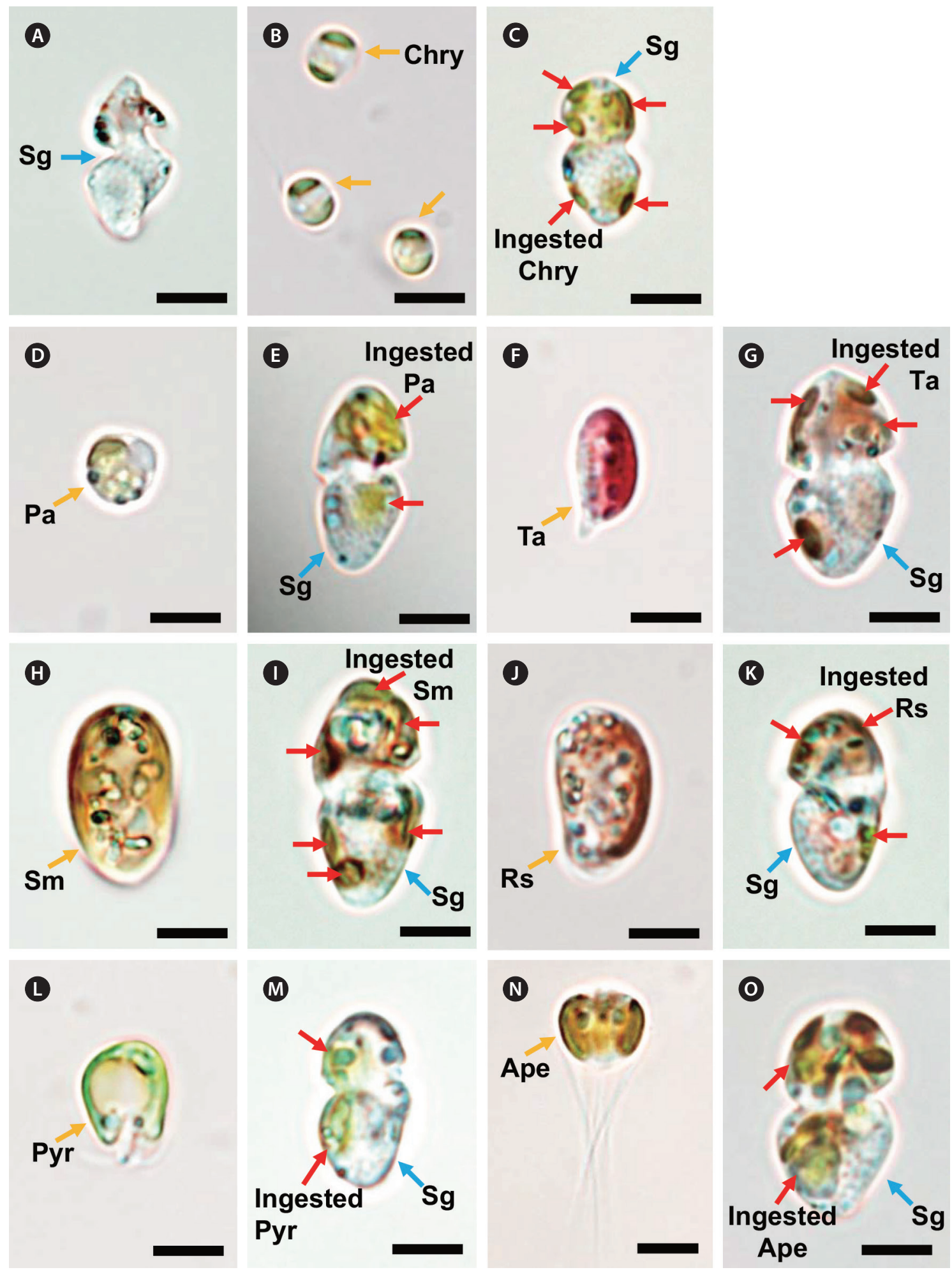

Fig. 4. Feeding by the kleptoplastidic dinoflagellate Shimiella gracilenta SGJH1904 (Sg) on algal prey species. (A) A starved Sg cell. (B) Intact Chrysochromulina sp. (Chry) cells. (C) Sg with ingested Chry cells. (D) An intact Phaeocystis antarctica (Pa) cell. (E) Sg with ingested Pa cells. (F) An intact Teleaulax amphioxeia (Ta) cell. (G) Sg with ingested Ta cells. (H) An intact Storeatula major (Sm) cell. (I) Sg with ingested Sm cells. (J) An intact Rhodomonas salina (Rs) cell. (K) Sg with ingested Rs cells. (L) An intact Pyramimonas sp. (Pyr) cell. (M) Sg with ingested Pyr cells. (N) An intact Apedinella sp. (Ape) cell. (O) Sg with ingested Ape cells. Scale bars represent: A-O, $5 \mu \mathrm{m}$. 


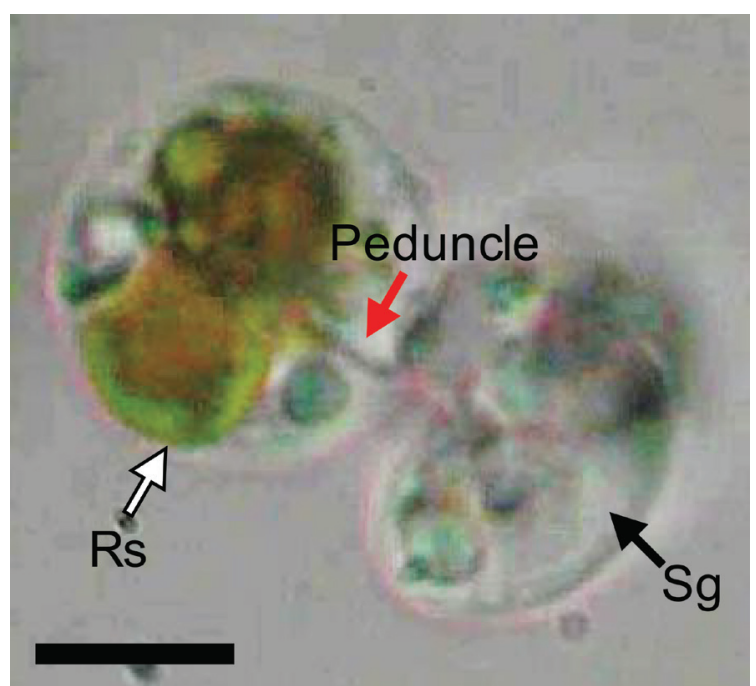

Fig. 5. Feeding by the kleptoplastidic dinoflagellate Shimiella gracilenta SGJH1904 (Sg) on the cryptophyte Rhodomonas salina (Rs) cell. The red arrow indicates the peduncle of $\mathrm{Sg}$. Scale bar represents: $5 \mu \mathrm{m}$.

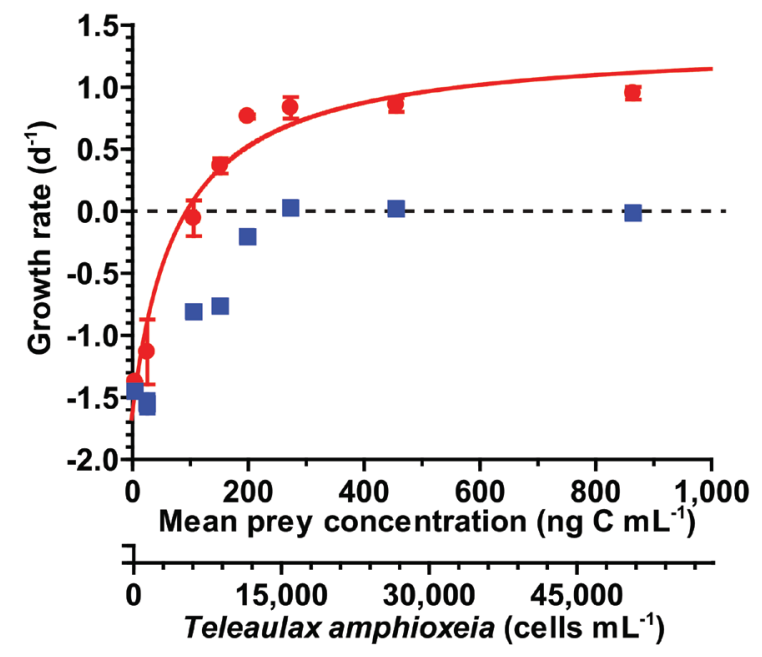

Fig. 6. Specific growth rates of Shimiella gracilenta SGJH1904 feeding on Teleaulax amphioxeia cells as a function of mean prey concentration ( $x, \mathrm{ng} \mathrm{C} \mathrm{mL}^{-1}$; red circles) or its filtrate of corresponding mean prey concentration (blue squares) (see Table 2). Symbols represent the treatment mean \pm standard error. The curves were fitted to a Michaelis-Menten equation (Eq. 2). Growth rate $\left(d^{-1} ;\right.$ red line $)=1.36[(x-$ 95.5) $/\{173+(x-95.5)\}], r^{2}=0.957$.

at higher mean prey concentrations (Fig. 6). When these data were fitted to equation (2), the $\mu_{\max }$ and $\mathrm{K}_{\mathrm{GR}}$ of S. gracilenta feeding on T. amphioxeia were $1.36 \mathrm{~d}^{-1}$ and $173 \mathrm{ng} \mathrm{C}$ $\mathrm{mL}^{-1}\left(10,176\right.$ cells $\left.\mathrm{mL}^{-1}\right)$, respectively. The threshold prey concentration for the growth of $S$. gracilenta was $95.5 \mathrm{ng}$ $\mathrm{C} \mathrm{mL}{ }^{-1}\left(5,618\right.$ cells $\left.\mathrm{mL}^{-1}\right)$. The highest specific growth rate of S. gracilenta with T. amphioxeia filtrate (without T. amphioxeia prey cells) was $0.03 \mathrm{~d}^{-1}$ (Fig. 6).

\section{Effects of filtrates of prey culture and $f / 2$ medium on the growth rate}

At a single high $S$. gracilenta concentration $(5,000$ cells $\mathrm{mL}^{-1}$ ), the specific growth rates of S. gracilenta SGJH1904 with $T$. amphioxeia cells, only $T$. amphioxeia filtrates, $\mathrm{f} / 2$ medium, and without any addition were significantly different (one-way ANOVA, $F_{3,8}=242.3, \mathrm{p}<0.001$ ) (Fig. 7). The growth rate of $S$. gracilenta with T. amphioxeia filtrate $\left(0.02 \mathrm{~d}^{-1}\right)$ was significantly higher than that with $\mathrm{f} / 2$ medium $\left(-0.15 \mathrm{~d}^{-1}\right)$ or without any additions $\left(-0.24 \mathrm{~d}^{-1}\right)$.

\section{Effects of prey concentration on the ingestion rate}

With increasing mean prey concentrations, the ingestion rate of S. gracilenta SGJH1904 on T. amphioxeia increased rapidly at mean prey concentrations of $\leq 199 \mathrm{ng} \mathrm{C}$ $\mathrm{mL}^{-1}\left(11,697\right.$ cells $\left.\mathrm{mL}^{-1}\right)$, but became saturated at higher mean prey concentrations (Fig. 8). When these data were fitted to equation (3), the $\mathrm{I}_{\max }$ and $\mathrm{K}_{\mathrm{IR}}$ of $S$. gracilenta feeding on T. amphioxeia were $0.04 \mathrm{ng} \mathrm{C}$ predator ${ }^{-1} \mathrm{~d}^{-1}(2.35$ cells predator-1 $\mathrm{d}^{-1}$ ) and $10.5 \mathrm{ng} \mathrm{C} \mathrm{mL} \mathrm{m}^{-1}$ (618 cells $\mathrm{mL}^{-1}$ ), respectively.

\section{DISCUSSION}

The present study demonstrates that $S$. gracilenta has a wide spatial distribution in Korean coastal waters from $33^{\circ} 14^{\prime} \mathrm{N}$ to $38^{\circ} 10^{\prime} \mathrm{N}$. Prior to the present study, S. gracilenta was reported in the waters from $29^{\circ} \mathrm{N}$ to $80^{\circ} \mathrm{N}$; Kuwait coastal waters $\left(29^{\circ} \mathrm{N}\right)$ (Al-Mutairi et al. 2020), U. S. coastal waters $\left(34^{\circ} \mathrm{N}\right)$ (Campbell 1973), Korean coastal waters $\left(35^{\circ} \mathrm{N}\right)\left(\mathrm{Ok}\right.$ et al. 2021a), Scandinavian waters $\left(51-55^{\circ} \mathrm{N}\right)$ (Skovgaard 1998, Martin and Gypens 2021), and the Arctic Ocean $\left(69-80^{\circ} \mathrm{N}\right)$ (de Sousa 2020, Back et al. 2021). These regions are all located in the northern hemisphere, and S. gracilenta cells have not been reported to be present in the Southern Hemisphere. Hence, additional data on the distribution and abundance of S. gracilenta on a global geographic scale are needed.

In the present study, S. gracilenta was found during all four seasons in the period from 2015 to 2018 and at $1.7-26.4^{\circ} \mathrm{C}$, indicating that $S$. gracilenta has a wide temporal distribution. However, the highest abundance of $S$. gracilenta was observed in summer when the water temperature was $20.4^{\circ} \mathrm{C}$ in the study area. Furthermore, the abundance of $S$. gracilenta was positively correlated with water temperature. In addition, Campbell (1973), who 


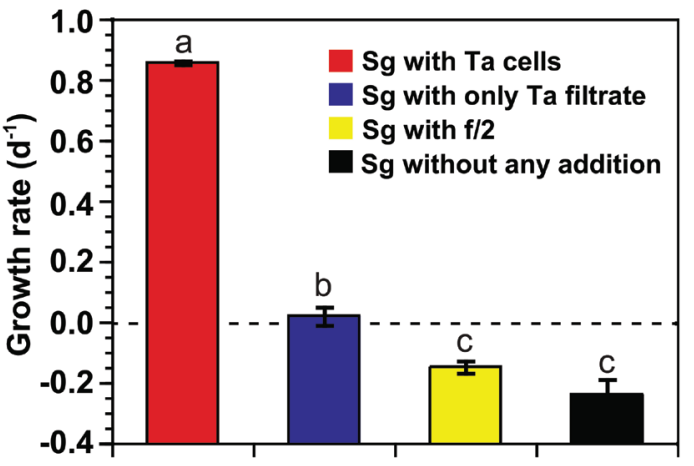

Fig. 7. Comparisons of specific growth rates of Shimiella gracilenta SGJH1904 (Sg) under different nutritional conditions (with Teleaulax amphioxeia [Ta] cells, only Ta filtrates, and $\mathrm{f} / 2$ medium, and without any addition) at a single high $\mathrm{Sg}$ concentration. The lowercase alphabetical letters above each bar indicate significantly different groups divided by a post-hoc Tukey's honestly significant difference test.

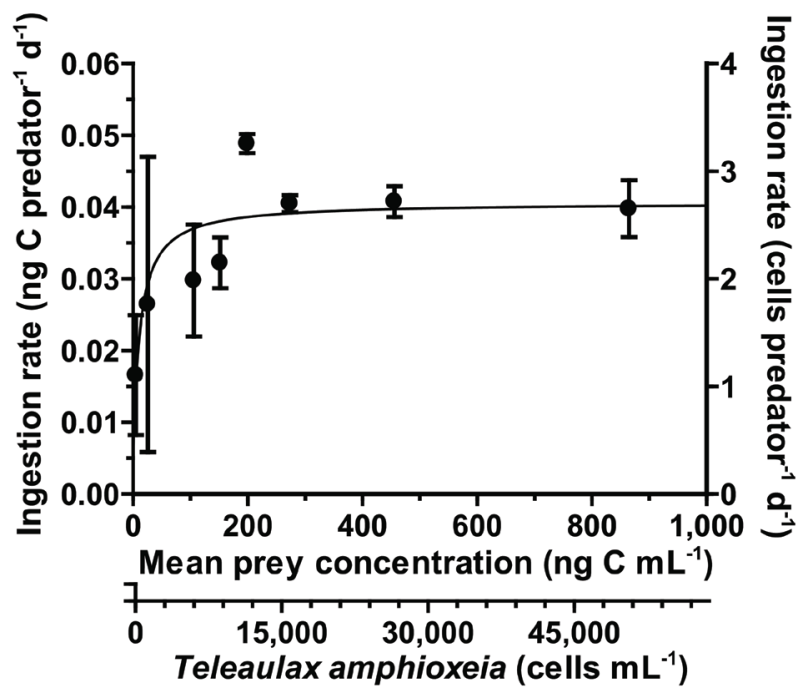

Fig. 8. Ingestion rates of Shimiella gracilenta SGJH1904 feeding on Teleaulax amphioxeia as a function of mean prey concentration $(x, \mathrm{ng}$ $\left.\mathrm{C} \mathrm{mL}^{-1}\right)$. Symbols represent the treatment mean \pm standard error. The curve was fitted to a Michaelis-Menten equation (Eq. 3). Ingestion rate $\left(\mathrm{ng} \mathrm{C}\right.$ predator $\left.{ }^{-1} \mathrm{~d}^{-1}\right)=0.04[x /(10.5+x)], \mathrm{r}^{2}=0.267$.

had first described S. gracilenta (reported as G. gracilentum), reported that the highest abundance in Gales Creek was observed in summer (18 cells $\left.\mathrm{mL}^{-1}\right)$. This evidence suggests that the abundance of $S$. gracilenta is seasonal.

The abundance of $S$. gracilenta was negatively correlated with salinity. The salinity range when $S$. gracilenta cells were detected was very wide (9.9-35.6). Campbell (1973) also reported that this species was present in a similar salinity range of 9-30. Thus, S. gracilenta may survive in estuaries, where salinity fluctuates due to freshwater or effluent inputs. In Kuwait Bay, S. gracilenta was observed under a microscope at a salinity of approximately 44 (AlMutairi et al. 2020). Thus, S. gracilenta can survive under high-salinity conditions. Therefore, the reported salinity range of S. gracilenta cells was from 9 to 44 , indicating that it is a euryhaline species. Overall, these euryhaline and eurythermal characteristics of S. gracilenta may be partially responsible for its wide spatial and temporal distributions in Korean waters.

The growth rate of S. gracilenta SGJH1904 was largely affected by T. amphioxeia prey concentration; thus, prey availability may strongly affect its abundance. Shimiella gracilenta (G. gracilentum) has been known to feed on cryptophytes Chroomonas sp., Plagioselmis prolonga, Rhodomonas marina, R. salina, and T. amphioxeia (Jakobsen et al. 2000). However, the present study clearly showed that $S$. gracilenta was able to feed on prymnesiophytes, a prasinophyte, a dictyochophyte, and another cryptophyte S. major. Moreover, S. gracilenta can reportedly utilize kleptoplastidy to survive for approximately one month in the absence of prey (Ok et al. 2021a). Thus, its ability to feed on diverse prey and conduct kleptoplastidy may also contribute to the wide spatial and temporal distributions of $S$. gracilenta in Korean waters.

In the present study, the highest abundance of $S$. gracilenta was only 2.96 cells $\mathrm{mL}^{-1}$, although cells were detected in all the 28 stations. The threshold T. amphioxeia prey concentration for $S$. gracilenta (i.e., no growth) in the present study was 5,618 cells $\mathrm{mL}^{-1}\left(95.5 \mathrm{ng} \mathrm{C} \mathrm{mL}^{-1}\right)$. However, the highest abundance of T. amphioxeia dur-

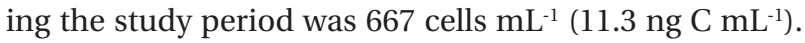
Using the equation in Fig. 6 and the abundance of $T$. amphioxeia during the study period from 2015 to 2018, the calculated specific growth rates of $S$. gracilenta on T. amphioxeia were negative $\left(-1.7\right.$ to $\left.-1.3 \mathrm{~d}^{-1}\right)$. Therefore, the abundance of T. amphioxeia in Korean waters during the study period was likely insufficient to support the positive growth of $S$. gracilenta. Furthermore, in the present study, the abundance of $S$. gracilenta was not significantly correlated with the abundance of T. amphioxeia or Pyramimonas sp. The low abundance of T. amphioxeia or Pyramimonas sp. may be partially responsible for this insignificant correlation. However, the maximum growth rates of S. gracilenta on suitable prey species were 1.36$1.51 \mathrm{~d}^{-1}$, which are among the highest maximum growth rates of dinoflagellates feeding on T. amphioxeia (Table 7). Thus, there is a possibility that the abundance of $S$. gracilenta rapidly increases if the abundance of $T$. amphioxeia is higher than 5,618 cells $\mathrm{mL}^{-1}$ in natural environments. The abundance of cryptophytes, including the genus Teleaulax, in natural seawater, has been reported 
as 392,440 cells $\mathrm{mL}^{-1}\left(6,671 \mathrm{ng} \mathrm{C} \mathrm{mL}^{-1}\right)$ in Masan Bay, Korea, 15,720 cells $\mathrm{mL}^{-1}$ (267 $\mathrm{ng} \mathrm{C} \mathrm{mL}^{-1}$ ) in Chesapeake Bay, USA, and 2,173 cells $\mathrm{mL}^{-1}$ (37 $\mathrm{ng} \mathrm{C} \mathrm{mL}^{-1}$ ) in Blanes Bay, Spain (Jeong et al. 2013, Johnson et al. 2013, Unrein et al. 2014). Assuming that all cryptophytes are T. amphioxeia in natural seawaters, the specific growth rates of $S$. gracilenta were calculated to be $1.33 \mathrm{~d}^{-1}$ in Masan Bay, $0.68 \mathrm{~d}^{-1}$ in Chesapeake Bay, and $-0.70 \mathrm{~d}^{-1}$ in Blanes Bay. Therefore, $S$. gracilenta is expected to be highly abundant in Masan Bay, moderately abundant in Chesapeake Bay, and rare in Blanes Bay under these prey concentrations.

When S. gracilenta was detected during 2015-2018, the highest Chl- $a$ was $59 \mathrm{ng} \mathrm{mL}^{-1}$, which was calculated to be 2,360 $\mathrm{ng} \mathrm{C} \mathrm{mL}{ }^{-1}$, assuming a carbon to chlorophyll ratio of 40 (Cloern et al. 1983, Peterson and Festa 1984). This carbon value is much higher than the threshold T. amphioxeia prey concentration for S. gracilenta. Based on the results of high Chl- $a$ but low abundance of S. gracilenta during the study period, it is suggested that phytoplankton species that are not fed on by $S$. gracilenta may have contributed to the high Chl- $a$.

Identifying $S$. gracilenta in field samples under a light microscope is difficult because cells of $S$. gracilenta are very small (9.3 $\mu \mathrm{m}$ in ESD) (Park et al. 2021) and fragile. Since the abundance of S. gracilenta during 2015-2018 was generally low, this study confirmed the detection of $S$. gracilenta by qPCR using a suitable prey enrichment and incubation method. The present study successfully confirmed that $S$. gracilenta cells were present even when $<1$ cell $\mathrm{mL}^{-1}$ of $S$. gracilenta was detected by qPCR. In conclusion, the qPCR method used in the present study is a suitable method for quantifying $S$. gracilenta abundance in natural seawaters, as well as a suitable prey enrichment and incubation method for confirming the presence of low abundance of S. gracilenta.

The $\mathrm{I}_{\max }$ of S. gracilenta on T. amphioxeia in the present study and the literature (0.04-0.08 ng C predator $\left.{ }^{-1} \mathrm{~d}^{-1}\right)$ is comparable to that of the mixotrophic dinoflagellates Prorocentrum donghainese, Prorocentrum micans, Heterocapsa steinii, and Gymnodinium aureolum (0.03-0.06 ng $\mathrm{C}$ predator $\left.{ }^{-1} \mathrm{~d}^{-1}\right)$, but lower than that of many mixotrophic, kleptoplastidic, and heterotrophic dinoflagellates on the same prey species (Table 7). Furthermore, the peduncle-feeding $S$. gracilenta has an $\mathrm{I}_{\max }$ comparable to that of G. aureolum but lower than that of other peduncle-feeding dinoflagellates $\left(0.18-1.10 \mathrm{ng} \mathrm{C}\right.$ predator $\left.^{-1} \mathrm{~d}^{-1}\right)$. Although the $\mathrm{I}_{\max }$ of $S$. gracilenta on T. amphioxeia was relatively low, the $\mu_{\max }$ of $S$. gracilenta on $T$. amphioxeia was greater than that of the other dinoflagellates on the same prey species. The ratio of the newly produced carbon by S. gracilenta SGJH1904 to ingested prey carbon, calculated as described by Skovgaard (1998), was >1.0. Thus, S. gracilenta SGJH1904 may conduct kleptoplastidy during satiation with prey cells as well as starvation.

Table 7. Comparison of the maximum growth and ingestion rates of dinoflagellate predators feeding on the cryptophyte Teleaulax amphioxeia

\begin{tabular}{|c|c|c|c|c|c|c|}
\hline Predator & Type & $\begin{array}{c}\text { Feeding } \\
\text { mechanism }\end{array}$ & ESD & $\mu_{\max }$ & $\mathbf{I}_{\max }$ & Reference \\
\hline Shimiella gracilenta & KPD & Peduncle & 9.3 & 1.36 & 0.04 & Park et al. (2021), This study \\
\hline Shimiella gracilenta ${ }^{\mathrm{a}}$ & KPD & Peduncle & $9.8^{\mathrm{b}}$ & 1.51 & $0.08^{\mathrm{c}}$ & Skovgaard (1998), Jakobsen et al. (2000) \\
\hline Yihiella yeosuensis $^{\mathrm{a}}$ & MTD & Engulfment & 7.8 & 1.29 & 0.38 & Jang et al. (2017) \\
\hline Pfiesteria piscicida & KPD & Peduncle & $8.7^{\mathrm{d}}$ & 1.15 & 1.10 & Burkholder et al. (2001), Jeong et al. (2006) \\
\hline Gyrodiniellum shiwhaense & HTD & Peduncle & 12.7 & 1.05 & 0.35 & Jeong et al. (2011) \\
\hline Paragymnodinium shiwhaense ${ }^{\mathrm{a}}$ & MTD & Peduncle & 12.4 & 0.64 & 0.18 & Yoo et al. (2010) \\
\hline Prorocentrum donghaiense & MTD & Engulfment & 13.3 & 0.51 & 0.03 & Jeong et al. (2005a) \\
\hline Margalefidinium polykrikoides & MTD & Engulfment & 23.1 & 0.32 & 0.16 & Jeong et al. (2004) \\
\hline Heterocapsa steinii & MTD & Engulfment & 15.0 & 0.28 & 0.04 & Jeong et al. $(2005 a)$ \\
\hline Gonyaulax polygramma & MTD & Engulfment & 32.5 & 0.28 & 0.18 & Jeong et al. $(2005 b)$ \\
\hline Luciella masanensis & HTD & Peduncle & 13.5 & 0.24 & 0.44 & Jeong et al. (2007) \\
\hline Prorocentrum micans & MTD & Engulfment & 26.6 & 0.20 & 0.04 & Jeong et al. (2005a) \\
\hline Gymnodinium aureolum $^{\mathrm{a}}$ & MTD & Peduncle & 19.4 & 0.17 & 0.06 & Jeong et al. $(2010 a)$ \\
\hline Bicheleria cincta $^{\mathrm{a}}$ & MTD & Peduncle & 13.4 & 0.16 & 0.19 & Kang et al. (2011) \\
\hline
\end{tabular}

ESD, equivalent spherical diameter $(\mu \mathrm{m}) ; \mu_{\max }$, maximum growth rate $\left(\mathrm{d}^{-1}\right) ; I_{\max }$, maximum ingestion growth rate $\left(\mathrm{ng} C\right.$ predator $\left.\mathrm{d}^{-1}\right) ; \mathrm{KPD}, \mathrm{klepto}$ plastidic dinoflagellate; MTD, mixotrophic dinoflagellate; HTD, heterotrophic dinoflagellate.

${ }^{a} \mu_{\max }$ and $I_{\max }$ of the species at a single prey concentration.

${ }^{\mathrm{b}}$ The ESD was calculated from the highest cell volume.

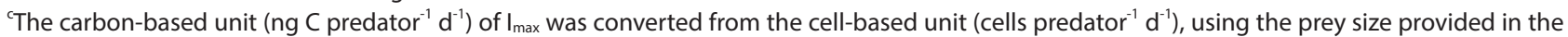
literature and the regression equation from Strathmann (1967).

${ }^{\mathrm{d}}$ The ESD was calculated from the highest cell volume when Pfiesteria piscicida fed on T. amphioxeia. 


\begin{tabular}{|c|c|c|c|c|c|c|c|c|c|}
\hline \multirow{2}{*}{$\begin{array}{ll}\text { Prey } & \text { Predator } \\
\end{array}$} & \multicolumn{2}{|c|}{ Shimiella } & \multicolumn{2}{|c|}{ Karenia } & \multicolumn{3}{|c|}{ Karlodinium } & \multicolumn{2}{|c|}{ Takayama } \\
\hline & $\begin{array}{l}\text { gracil- } \\
\text { enta }\end{array}$ & RSD & $\begin{array}{l}\text { miki- } \\
\text { motoi }\end{array}$ & brevis & $\begin{array}{c}\text { armi- } \\
\text { ger }\end{array}$ & $\begin{array}{l}\text { aust- } \\
\text { rale }\end{array}$ & $\begin{array}{l}\text { vene- } \\
\text { ficum }\end{array}$ & helix & $\begin{array}{c}\text { tas- } \\
\text { manica }\end{array}$ \\
\hline $\begin{array}{l}\text { Cyanobacterium } \\
\text { Synechococcus sp. }\end{array}$ & & & & 0 & & & & & \\
\hline $\begin{array}{l}\text { Prymnesiophyte } \\
\text { Chrysochromulina sp. } \\
\text { Phaeocystis antarctica }\end{array}$ & $\begin{array}{l}0 \\
0\end{array}$ & 0 & & & 0 & & & & \\
\hline Isochrysis galbana & $\mathrm{x}$ & & 0 & & 0 & & 0 & $\mathrm{x}$ & $\mathrm{x}$ \\
\hline Cryptophyte & & & & & & & & & \\
\hline $\begin{array}{l}\text { Teleaulax amphioxeia } \\
\text { Storeatula major } \\
\text { Rhodomonas salina }\end{array}$ & $\begin{array}{l}0 \\
0\end{array}$ & & & & 0 & & 0 & $\begin{array}{l}x \\
x\end{array}$ & $\begin{array}{l}x \\
x\end{array}$ \\
\hline $\begin{array}{l}\text { Rhodomonas salina } \\
\text { Prasinophyte } \\
\text { Pyramimonas sp. }\end{array}$ & 0 & & & & 0 & 0 & 0 & $\mathrm{x}$ & $\mathrm{x}$ \\
\hline $\begin{array}{l}\text { Chlorophyte } \\
\text { Dunaliella salina }\end{array}$ & $\mathrm{x}$ & & & & & & & & \\
\hline $\begin{array}{l}\text { Dictyochophyte } \\
\text { Apedinella sp. } \\
\text { Pseudopedinella elastica }\end{array}$ & $\begin{array}{l}0 \\
\mathrm{x} \\
\end{array}$ & & & & & & & & \\
\hline $\begin{array}{l}\text { Raphidophyte } \\
\text { Heterosigma akashino }\end{array}$ & $\mathrm{x}$ & & & & 0 & & & $\mathrm{x}$ & $\mathrm{x}$ \\
\hline $\begin{array}{l}\text { Diatom } \\
\text { Skeletonema costatum }\end{array}$ & $\mathrm{x}$ & & & & & & & $\mathrm{x}$ & $x$ \\
\hline Dinoflagellate & & & & & & & & & \\
\hline $\begin{array}{l}\text { Heterocapsa rotundata } \\
\text { Amphidinium carterae }\end{array}$ & $\begin{array}{l}x \\
x\end{array}$ & & & & 0 & & & $\begin{array}{l}x \\
x\end{array}$ & $\begin{array}{l}x \\
x\end{array}$ \\
\hline Effrenium voratum & $x$ & & & & & & & & \\
\hline $\begin{array}{l}\text { Prorocentrum cordatum } \\
\text { Karlodinium veneficum }\end{array}$ & $\begin{array}{l}x \\
x\end{array}$ & & & & 0 & & & $\mathrm{x}$ & $\mathrm{x}$ \\
\hline $\begin{array}{l}\text { Heterocapsa steinii } \\
\text { Alexandrium minutum }\end{array}$ & $\begin{array}{l}x \\
x\end{array}$ & & & & 0 & & & $\begin{array}{l}0 \\
0\end{array}$ & $\begin{array}{l}0 \\
0\end{array}$ \\
\hline Karenia mikimotoi & $x$ & & & & & & & $x$ & $x$ \\
\hline Scrippsiella acuminata & $\mathrm{x}$ & & & & & & & 0 & 0 \\
\hline Margalefidinium polykrikoides & $\mathrm{x}$ & & & & & & 0 & 0 & 0 \\
\hline Prorocentrum micans & $\mathrm{x}$ & & & & 0 & & & $\mathrm{x}$ & $\mathrm{x}$ \\
\hline Akashiwo sanguinea & $\mathrm{x}$ & & & & 0 & & 0 & $\mathrm{x}$ & $\mathrm{x}$ \\
\hline $\begin{array}{l}\text { Tripos furca } \\
\text { Alexandrium fraterculus }\end{array}$ & $\begin{array}{l}x \\
x\end{array}$ & & & & & & & & \\
\hline Lingulodinium polyedra & $\mathrm{x}$ & & & & & & & 0 & 0 \\
\hline $\begin{array}{l}\text { Ciliate } \\
\text { Mesodinium rubrum }\end{array}$ & $\mathrm{x}$ & & & & & & & & \\
\hline Reference & (1) & (2) & (3) & (4) & (5) & (6) & $(7),(8)$ & (9) & (10) \\
\hline
\end{tabular}

Fig. 9. Feeding occurrence by each dinoflagellate predator belonging to the family Kareniaceae on diverse prey species. RSD, the Ross Sea dinoflagellate; $O$ in blue box, feeding; $X$ in red box, no feeding. 1, This study; 2, Sellers et al. (2014); 3, Zhang et al. (2011); 4, Glibert et al. (2009); 5 , Berge et al. (2008); 6, de Salas et al. (2005); 7, Li et al. (1999); 8, Yang et al. (2020); 9, Jeong et al. (2016); 10, Lim et al. (2018).

The specific growth rate of S. gracilenta SGJH1904 with T. amphioxeia filtrate was significantly higher than that with $\mathrm{f} / 2$ medium and without any addition. The materials in the prey filtrates were likely to increase the growth rates of S. gracilenta SGJH1904. Some phagotrophic dinoflagellates have been reported to utilize dissolved organic materials for their growth (Ou et al. 2014, Hattenrath-Lehmann and Gobler 2015). This evidence suggests that $S$. gracilenta may be able to maintain its abundance using dissolved organic materials released from prey cells.

Many species in the family Kareniaceae, to which $S$. gracilenta belongs, are known to be mixotrophic or kleptoplastidic dinoflagellates (Li et al. 1999, de Salas et al. 2005, Berge et al. 2008, Glibert et al. 2009, Zhang et al. 2011, Sellers et al. 2014, Jeong et al. 2016, Lim et al. 2018, Yang et al. 2020). Interestingly, the different genera in this family have different prey spectra (Fig. 9): Takayama spp. were observed to feed only on dinoflagellates (Jeong et al. 2016, Lim et al. 2018); Karenia spp. were observed to feed on a cyanobacterium or prymnesiophyte (Glibert et al. 2009, Zhang et al. 2011); Karlodinium spp. feed on diverse prey taxa including prymnesiophytes, cryptophytes, a prasinophyte, a raphidophyte, and dinoflagellates (Li et 
al. 1999, de Salas et al. 2005, Berge et al. 2008, Yang et al. 2020). Shimiella gracilenta was also observed to feed on various prey taxa, including prymnesiophytes, cryptophytes, a prasinophyte, and a dictyochophyte; however, we did not observe it feeding on dinoflagellates. A possibility that these genera acquired different kleptoplastids from different prey has been suggested (i.e., horizontal gene transfer) (Hehenberger et al. 2019). Thus, differences in the prey spectra among the genera in the family may have led to their generic divergence. Moreover, S. gracilenta was able to feed on the prymnesiophyte $P$. antarctica that the Ross Sea dinoflagellate, sister species of S. gracileta, selectively fed on (Sellers et al. 2014). The Ross Sea dinoflagellate was found in the Antarctic region, whereas S. gracilenta SGJH1904 was isolated from temperate coastal waters (Gast et al. 2006, Ok et al. 2021a). Therefore, S. gracilenta shared the same prey species as sister species, although they lived in largely different regions.

In conclusion, the ecophysiological characteristics of S. gracilenta can be summarized as follows: (1) S. gracilenta has a wide spatial and temporal distributions in Korean coastal waters; (2) it has the ability to survive in wide ranges of water temperature and salinity, ranging $1.7-26.4^{\circ} \mathrm{C}$ and 9.9-35.6, respectively; (3) S. gracilenta is able to feed on diverse prey species; and (4) it can divide more than twice a day if the optimal prey, T. amphioxeia, is abundant; but (5) it demands approximately 6,000 cells $\mathrm{mL}^{-1}$ of T. amphioxeia as a threshold concentration for growth. Overall, its eurythermal and euryhaline characteristics and the ability to feed on diverse prey species and conduct kleptoplastidy may be responsible for its wide spatial and temporal distributions.

\section{ACKNOWLEDGEMENTS}

This research was supported by the National Research Foundation funded by the Ministry of Science and ICT (NRF-2020M3F6A1110582; NRF-2021M3I6A1091272; NRF2021R1A2C1093379) and by the useful dinoflagellate program of Korea Institute of Marine Science and Technology Promotion (KIMST) funded by the Ministry of Oceans and Fisheries (MOF) award to HJJ.

\section{CONFLICTS OF INTEREST}

The authors declare that they have no potential conflicts of interest.

\section{SUPPLEMENTARY MATERIALS}

Supplementary Table S1. Sampling date of field samples during 2015-2018 (https:/ /www.e-algae.org).

Supplementary Table S2. List of aligned sequences of the internal transcribed spacer region of ribosomal DNA obtained from GenBank to develop the species-specific primers and probe of Shimiella gracilenta (https://www. e-algae.org).

Supplementary Table S3. List of species used to examine primer and probe specificity for Shimiella gracilenta and quantitative real-time polymerase chain reaction results (https://www.e-algae.org).

Supplementary Table S4. Taxa and conditions for the isolation of the kleptoplastidic dinoflagellate Shimiella gracilenta SGJH1904 and experimental prey organisms used for experiment 1 (https://www.e-algae.org).

Supplementary Fig. S1. Standard curve determined by plotting the cycle threshold $(\mathrm{Ct})$ as a function of log (cell abundance) of Shimiella gracilenta (https://www.ealgae.org).

\section{REFERENCES}

Al-Mutairi, M., Subrahmanyam, M. N. V., Ali, M., Isath, S., AlAwadi, M. A., Kumar, P. N., Al-Hebini, K. \& Omar, S. A. S. 2020. Temporal variations in abundance and species richness of phytoplankton with emphasis on diatoms in the subtidal waters of Umm Al-Namil Island, northwestern Arabian Gulf of the ROPME Sea Area. J. Environ. Biol. 41:1470-1485.

Back, D. -Y., Ha, S. -Y., Else, B., Hanson, M., Jones, S. F., Shin, K. -H., Tatarek, A., Wiktor, J. M., Cicek, N., Alam, S. \& Mundy, C. J. 2021. On the impact of wastewater effluent on phytoplankton in the Arctic coastal zone: a case study in the Kitikmeot Sea of the Canadian Arctic. Sci. Total Environ. 764:143861.

Baek, S. H., Shimode, S., Han, M. -S. \& Kikuchi, T. $2008 a$. Growth of dinoflagellates, Ceratium furca and Ceratium fusus in Sagami Bay, Japan: the role of nutrients. Harmful Algae 7:729-739.

Baek, S. H., Shimode, S. \& Kikuchi, T. 2008b. Growth of dinoflagellates, Ceratium furca and Ceratium fusus in Sagami Bay, Japan: the role of temperature, light intensity and photoperiod. Harmful Algae 7:163-173.

Berge, T., Hansen, P. J. \& Moestrup, Ø. 2008. Feeding mechanism, prey specificity and growth in light and dark of the plastidic dinoflagellate Karlodinium armiger. Aquat. Microb. Ecol. 50:279-288. 
Bockstahler, K. R. \& Coats, D. W. 1993. Spatial and temporal aspects of mixotrophy in Chesapeake Bay dinoflagellates. J. Eukaryot. Microbiol. 40:49-60.

Booth, B. C. \& Smith, W. O. Jr. 1997. Autotrophic flagellates and diatoms in the Northeast Water Polynya, Greenland: summer 1993. J. Mar. Syst. 10:241-261.

Burkholder, J. M., Glasgow, H. B. \& Deamer-Mella, N. 2001. Overview and present status of the toxic Pfiesteria complex (Dinophyceae). Phycologia 40:186-214.

Campbell, P. H. 1973. The phytoplankton of Gales Creek with emphasis on the taxonomy and ecology of estuarine phytoflagellates. Ph.D. dissertation, University of North Carolina, Chapel Hill, NC, USA, 354 pp.

Cloern, J. E., Alpine, A. E., Cole, B. E., Wong, R. L. J., Arthur, J. F. \& Ball, M. D. 1983. River discharge controls phytoplankton dynamics in the northern San Francisco Bay estuary. Estuar. Coast. Shelf Sci. 16:415-429.

Coats, D. W. 1999. Parasitic life styles of marine dinoflagellates. J. Eukaryot. Microbiol. 46:402-409.

Cohu, S., Thibaut, T., Mangialajo, L., Labat, J. -P., Passafiume, O., Blanfuné, A., Simon, N., Cottalorda, J. -M. \& Lemée, R. 2011. Occurrence of the toxic dinoflagellate Ostreopsis cf. ovata in relation with environmental factors in Monaco (NW Mediterranean). Mar. Pollut. Bull. 62:2681-2691.

Díaz, P., Molinet, C., Cáceres, M. A. \&Valle-Levinson, A. 2011. Seasonal and intratidal distribution of Dinophysis spp. in a Chilean fjord. Harmful Algae 10:155-164.

Drira, Z., Hamza, A., Belhassen, M., Ayadi, H., Bouaïn, A. \& Aleya, L. 2008. Dynamics of dinoflagellates and environmental factors during the summer in the Gulf of Gabes (Tunisia, Eastern Mediterranean Sea). Sci. Mar. 72:59-71.

de Salas, M. F., Bolch, C. J. S. \& Hallegraeff, G. M. 2005. Karlodinium australe sp. nov. (Gymnodiniales, Dinophyceae), a new potentially ichthyotoxic unarmoured dinoflagellate from lagoonal habitats of south-eastern Australia. Phycologia 44:640-650.

de Sousa, M. I. L. 2020. Biogeography of Arctic Eukaryotic Microbiome: A comparative approach between $18 \mathrm{~S}$ rRNA gene metabarcoding and microscopic analysis. M.S. dissertation, University of Porto, Porto, Portugal, $94 \mathrm{pp}$.

Eom, S. H., Jeong, H. J., Ok, J. H., Park, S. A., Kang, H. C., You, J. H., Lee, S. Y., Yoo, Y. D., Lim, A. S. \& Lee, M. J. 2021. Interactions between common heterotrophic protists and the dinoflagellate Tripos furca: implication on the long duration of its red tides in the South Sea of Korea in 2020. Algae 36:25-36.

Fraga, S., Rodríguez, F., Bravo, I., Zapata, M. \& Marañón,
E. 2012. Review of the main ecological features affecting benthic dinoflagellate blooms. Cryptogam. Algol. 33:171-179.

Frost, B. W. 1972. Effects of size and concentration of food particles on the feeding behavior of the marine planktonic copepod Calanus pacificus. Limnol. Oceanogr. 17:805-815.

Gast, R. J., Moran, D. M., Beaudoin, D. J., Blythe, J. N., Dennett, M. R. \& Caron, D. A. 2006. Abundance of a novel dinoflagellate phylotype in the Ross Sea, Antarctica. J. Phycol. 42:233-242.

Gast, R. J., Moran, D. M., Dennett, M. R. \& Caron, D. A. 2007. Kleptoplasty in an Antarctic dinoflagellate: caught in evolutionary transition? Environ. Microbiol. 9:39-45.

Gímez, M. I., Piola, A. R., Kattner, G. \& Alder, V. A. 2011. Biomass of autotrophic dinoflagellates under weak vertical stratification and contrasting chlorophyll levels in subantarctic shelf waters. J. Plankton Res. 33:1304-1310.

Glibert, P. M., Burkholder, J. M., Kana, T. M., Alexander, J., Skelton, H. \& Shilling, C. 2009. Grazing by Karenia brevis on Synechococcus enhances its growth rate and may help to sustain blooms. Aquat. Microb. Ecol. 55:17-30.

Golubkov, M., Nikulina, V. \& Golubkov, S. 2019. Effects of environmental variables on midsummer dinoflagellate community in the Neva Estuary (Baltic Sea). Oceanologia 61:197-207.

Guillard, R. R. L. \& Hargraves, P. E. 1993. Stichochrysis immobilis is a diatom, not a chrysophyte. Phycologia 32:234-236.

Guillard, R. R. L. \& Ryther, J. H. 1962. Studies of marine planktonic diatoms: I. Cyclotella nana Hustedt, and Detonula confervacea (Cleve) Gran. Can. J. Microbiol. 8:229-239.

Hallegraeff, G. M. 1993. A review of harmful algal blooms and their apparent global increase. Phycologia 32:79-99.

Hansen, P. J. 1991 $a$. Dinophysis: a planktonic dinoflagellate genus which can act both as a prey and a predator of a ciliate. Mar. Ecol. Prog. Ser. 69:201-204.

Hansen, P. J. 1991b. Quantitative importance and trophic role of heterotrophic dinoflagellates in a coastal pelagial food web. Mar. Ecol. Prog. Ser. 73:253-261.

Hattenrath-Lehmann, T. \& Gobler, C. J. 2015. The contribution of inorganic and organic nutrients to the growth of a North American isolate of the mixotrophic dinoflagellate, Dinophysis acuminata. Limnol. Oceanogr. 60:1588-1603.

Hehenberger, E., Gast, R. J. \& Keeling, P. J. 2019. A kleptoplastidic dinoflagellate and the tipping point between transient and fully integrated plastid endosymbiosis. Proc. Natl. Acad. Sci. 116:17934-17942.

Heinbokel, J. F. 1978. Studies on the functional role of tin- 
tinnids in the Southern California Bight. I. Grazing and growth rates in laboratory cultures. Mar. Biol. 47:177-189.

Hernández-Becerril, D. U., Lau, W. L. S., Hii, K. S., Leaw, C. P., Varona-Cordero, F. \& Lim, P. T. 2018. Abundance and distribution of the potentially toxic thecate dinoflagellate Alexandrium tamiyavanichii (Dinophyceae) in the Central Mexican Pacific, using the quantitative PCR method. Front. Mar. Sci. 5:366.

Jakobsen, H. H., Hansen, P. J. \& Larsen, J. 2000. Growth and grazing responses of two chloroplast-retaining dinoflagellates: effect of irradiance and prey species. Mar. Ecol. Prog. Ser. 201:121-128.

Jang, S. H. \& Jeong, H. J. 2020. Spatio-temporal distributions of the newly described mixotrophic dinoflagellate Yihiella yeosuensis (Suessiaceae) in Korean coastal waters and its grazing impact on prey populations. Algae 35:45-59.

Jang, S. H., Jeong, H. J., Kwon, J. E. \& Lee, K. H. 2017. Mixotrophy in the newly described dinoflagellate Yihiella yeosuensis: a small, fast dinoflagellate predator that grows mixotrophically, but not autotrophically. Harmful Algae 62:94-103.

Jeong, H. J. 1999. The ecological roles of heterotrophic dinoflagellates in marine planktonic community. J. Eukaryot. Microbiol. 46:390-396.

Jeong, H. J., Ha, J. H., Park, J. Y., Kim, J. H., Kang, N. S., Kim, S., Kim, J. S., Yoo, Y. D. \& Yih, W. H. 2006. Distribution of the heterotrophic dinoflagellate Pfiesteria piscicida in Korean waters and its consumption of mixotrophic dinoflagellates, raphidophytes and fish blood cells. Aquat. Microb. Ecol. 44:263-278.

Jeong, H. J., Ha, J. H., Yoo, Y. D., Park, J. Y., Kim, J. H., Kang, N. S., Kim, T. H., Kim, H. S. \& Yih, W. H. 2007. Feeding by the Pfiesteria-like heterotrophic dinoflagellate Luciella masanensis. J. Eukaryot. Microbiol. 54:231-241.

Jeong, H. J., Kang, H. C., Lim, A. S., Jang, S. H., Lee, K., Lee, S. Y., Ok, J. H., You, J. H., Kim, J. H., Lee, K. H., Park, S. A., Eom, S. H., Yoo, Y. D. \& Kim, K. Y. 2021 $a$. Feeding diverse prey as an excellent strategy of mixotrophic dinoflagellates for global dominance. Sci. Adv. 7:eabe4214.

Jeong, H. J., Lee, K. H., Yoo, Y. D., Kang, N. S. \& Lee, K. 2011. Feeding by the newly described, nematocyst-bearing heterotrophic dinoflagellate Gyrodiniellum shiwhaense. J. Eukaryot. Microbiol. 58:511-524.

Jeong, H. J., Lim, A. S., Franks, P. J. S., Lee, K. H., Kim, J. H., Kang, N. S., Lee, M. J., Jang, S. H., Lee, S. Y., Yoon, E. Y., Park, J. Y., Yoo, Y. D., Seong, K. A., Kwon, J. E. \& Jang, T. Y. 2015. A hierarchy of conceptual models of red-tide generation: nutrition, behavior, and biological interac- tions. Harmful Algae 47:97-115.

Jeong, H. J., Lim, A. S., Yoo, Y. D., Lee, M. J., Lee, K. H., Jang, T. Y. \& Lee, K. 2014. Feeding by heterotrophic dinoflagellates and ciliates on the free-living dinoflagellate Symbiodinium sp. (Clade E). J. Eukaryot. Microbiol. 61:27-41.

Jeong, H. J., Ok, J. H., Lim, A. S., Kwon, J. E., Kim, S. J. \& Lee, S. Y. 2016. Mixotrophy in the phototrophic dinoflagellate Takayama helix (family Kareniaceae): predator of diverse toxic and harmful dinoflagellates. Harmful Algae 60:92-106.

Jeong, H. J., Yoo, Y. D., Kang, N. S., Rho, J. R., Seong, K. A., Park, J. W., Nam, G. S. \& Yih, W. 2010a. Ecology of Gymnodinium aureolum. I. Feeding in western Korean waters. Aquat. Microb. Ecol. 59:239-255.

Jeong, H. J., Yoo, Y. D., Kim, J. S., Kim, T. H., Kim, J. H., Kang, N. S. \& Yih, W. 2004. Mixotrophy in the phototrophic harmful alga Cochlodinium polykrikoides (Dinophycean): prey species, the effects of prey concentration, and grazing impact. J. Eukaryot. Microbiol. 51:563-569.

Jeong, H. J., Yoo, Y. D., Kim, J. S., Seong, K. A., Kang, N. S. \& Kim, T. H. 2010b. Growth, feeding and ecological roles of the mixotrophic and heterotrophic dinoflagellates in marine planktonic food webs. Ocean Sci. J. 45:65-91.

Jeong, H. J., Yoo, Y. D, Lee, K., Kang, H. C., Kim, J. S. \& Kim, K. Y. 2021b. Annual carbon retention of a marine-plankton community in the eutrophic Masan Bay, based on daily measurements. Mar. Biol. 168:69.

Jeong, H. J., Yoo, Y. D., Lee, K. H., Kim, T. H., Seong, K. A., Kang, N. S., Lee, S. Y., Kim, J. S., Kim, S. \& Yih, W. H. 2013. Red tides in Masan Bay, Korea in 2004-2005: I. Daily variations in the abundance of red-tide organisms and environmental factors. Harmful Algae 30(Suppl. 1):S75-S88.

Jeong, H. J., Yoo, Y. D., Park, J. Y., Song, J. Y., Kim, S. T., Lee, S. H., Kim, K. W. \& Yih, W. H. 2005a. Feeding by phototrophic red-tide dinoflagellates: five species newly revealed and six species previously known to be mixotrophic. Aquat. Microb. Ecol. 40:133-150.

Jeong, H. J., Yoo, Y. D., Seong, K. A., Kim, J. H., Park, J. Y., Kim, S. H., Lee, S. H., Ha, J. H. \& Yih. W. H. 2005b. Feeding by the mixotrophic dinoflagellate Gonyaulax polygramma: mechanisms, prey species, effects of prey concentration, and grazing impact. Aquat. Microb. Ecol. 38:249-257.

Johnson, M. D. 2011. The acquisition of phototrophy: adaptive strategies of hosting endosymbionts and organelles. Photosynth. Res. 107:117-132.

Johnson, M. D., Stoecker, D. K. \& Marshall, H. G. 2013. Seasonal dynamics of Mesodinium rubrum in Chesapeake Bay. J. Plankton Res. 35:877-893.

Kang, H. C., Jeong, H. J., Lim, A. S., Ok, J. H., You, J. H., Park, S. A., Lee, S. Y. \& Eom, S. H. 2020. Effects of temperature on 
the growth and ingestion rates of the newly described mixotrophic dinoflagellate Yihiella yeosuensis and its two optimal prey species. Algae 35:263-275.

Kang, H. C., Jeong, H. J., Ok, J. H., You, J. H., Jang, S. H., Lee, S. Y., Lee, K. H., Park, J. Y. \& Rho, J. -R. 2019. Spatial and seasonal distributions of the phototrophic dinoflagellate Biecheleriopsis adriatica (Suessiaceae) in Korea: quantification using qPCR. Algae 34:111-126.

Kang, N. S., Jeong, H. J., Yoo, Y. D., Yoon, E. Y., Lee, K. H., Lee, K. \& Kim, G. 2011. Mixotrophy in the newly described phototrophic dinoflagellate Woloszynskia cincta from western Korean waters: feeding mechanism, prey species and effect of prey concentration. J. Eukaryot. Microbiol. 58:152-170.

Kibbe, W. A. 2007. OligoCalc: an online oligonucleotide properties calculator. Nucleic Acids Res. 35:W43-W46.

Kim, J. S., Jeong, H. J., Yoo, Y. D., Kang, N. S., Kim, S. K., Song, J. Y., Lee, M. J., Kim, S. T., Kang, J. H., Seong, K. A. \& Yih, W. H. 2013. Red tides in Masan Bay, Korea, in 2004-2005: III. Daily variations in the abundance of mesozooplankton and their grazing impacts on red-tide organisms. Harmful Algae 30(Suppl. 1):S102-S113.

Larsen, J. 1988. An ultrastructural study of Amphidinium poecilochroum (Dinophyceae), a phagotrophic dinoflagellate feeding on small species of cryptophytes. Phycologia 27:366-377.

Larsen, J. 1994. Unarmoured dinoflagellates from Australian waters I. The genus Gymnodinium (Gymnodiniales, Dinophyceae). Phycologia 33:24-33.

Lee, K. H., Jeong, H. J., Kang, H. C., Ok, J. H., You, J. H. \& Park, S. A. 2019a. Growth rates and nitrate uptake of cooccurring red-tide dinoflagellates Alexandrium affine and $A$. fraterculus as a function of nitrate concentration under light-dark and continuous light conditions. Algae 34:237-251.

Lee, K. H., Jeong, H. J., Kwon, J. E., Kang, H. C., Kim, J. H., Jang, S. H., Park, J. Y., Yoon, E. Y. \& Kim, J. S. 2016. Mixotrophic ability of the phototrophic dinoflagellates Alexandrium andersonii, A. affine, and A. fraterculus. Harmful Algae 59:67-81.

Lee, S. Y., Jeong, H. J., Kang, H. C., Ok, J. H., You, J. H., Park, S. A. \& Eom, S. H. 2021. Comparison of the spatial-temporal distributions of the heterotrophic dinoflagellates Gyrodinium dominans, G. jinhaense, and G. moestrupii in Korean coastal waters. Algae 36:37-50.

Lee, S. Y., Jeong, H. J., Kwon, J. E., You, J. H., Kim, S. J., Ok, J. H., Kang, H. C. \& Park, J. Y. 2019b. First report of the photosynthetic dinoflagellate Heterocapsa minima in the Pacific Ocean: morphological and genetic characterizations and the nationwide distribution in Korea.
Algae 34:7-21.

Lee, S. Y., Jeong, H. J., Ok, J. H., Kang, H. C. \& You, J. H. 2020. Spatial-temporal distributions of the newly described mixotrophic dinoflagellate Gymnodinium smaydae in Korean coastal waters. Algae 35:225-236.

Li, A., Stoecker, D. K. \& Adolf, J. E. 1999. Feeding, pigmentation, photosynthesis and growth of the mixotrophic dinoflagellate Gyrodinium galatheanum. Aquat. Microb. Ecol. 19:163-176.

Li, A., Stoecker, D. K. \& Coats, D. W. 2000. Spatial and temporal aspects of Gyrodinium galatheanum in Chesapeake Bay: distribution and mixotrophy. J. Plankton Res. 22:2105-2124.

Lim, A. S., Jeong, H. J., Ok, J. H. \& Kim, S. J. 2018. Feeding by the harmful phototrophic dinoflagellate Takayama tasmanica (Family Kareniaceae). Harmful Algae 74:19-29.

Lin, S., Zhang, H. \& Dubois, A. 2006. Low abundance distribution of Pfiesteria piscicida in Pacific and Western Atlantic as detected by mtDNA-18S rDNA real-time polymerase chain reaction. J. Plankton Res. 28:667-681.

Litaker, R. W., Vandersea, M. W., Kibler, S. R., Reece, K. S., Stokes, N. A., Steidinger, K. A., Millie, D. F., Bendis, B. J., Pigg, R. J. \& Tester, P. A. 2003. Identification of Pfiesteria piscicida (Dinophyceae) and Pfiesteria-like organisms using internal transcribed spacer-specific PCR assays. J. Phycol. 39:754-761.

Martin, J. R. \& Gypens, N. 2021. Temperate waters: NCM succession and spatial variability in The North Sea revealed by DNA metabarcoding. In Mitra, A., Hansen, P. J. \& Flynn, K. J. (Eds.) Report of Seasonal Distribution of Non-constitutive Mixoplankton across Arctic, Temperate and Mediterranean Coastal Waters. Zenodo, pp. 21-30.

Mathot, S., Smith, W. O. Jr., Carlson, C. A., Garrison, D. L., Gowing, M. M. \&Vickers, C. L. 2000. Carbon partitioning within Phaeocystis antarctica (Prymnesiophyceae) colonies in the Ross Sea, Antarctica. J. Phycol. 36:1049-1056.

Matsubara, T., Nagasoe, S., Yamasaki, Y., Shikata, T., Shimasaki, Y., Oshima, Y. \& Honjo, T. 2007. Effects of temperature, salinity, and irradiance on the growth of the dinoflagellate Akashiwo sanguinea. J. Exp. Mar. Biol. Ecol. 342:226-230.

Ok, J. H., Jeong, H. J., Lee, S. Y., Park, S. A. \& Noh, J. H. $2021 a$. Shimiella gen. nov. and Shimiella gracilenta sp. nov. (Dinophyceae, Kareniaceae), a kleptoplastidic dinoflagellate from Korean waters and its survival under starvation. J. Phycol. 57:70-91.

Ok, J. H., Jeong, H. J., Lim, A. S. \& Lee, K. H. 2017. Interactions between the mixotrophic dinoflagellate Takayama helix and common heterotrophic protists. Harmful Algae 68:178-191. 
Ok, J. H., Jeong, H. J., Lim, A. S., You, J. H., Kang, H. C., Kim, S. J. \& Lee, S. Y. 2019. Effects of light and temperature on the growth of Takayama helix (Dinophyceae): mixotrophy as a survival strategy against photoinhibition. J. Phycol. 55:1181-1195.

Ok, J. H., Jeong, H. J., You, J. H., Kang, H. C., Park, S. A., Lim, A. S., Lee, S. Y. \& Eom, S. H. 2021b. Phytoplankton bloom dynamics in incubated natural seawater: predicting bloom magnitude and timing. Front. Mar. Sci. 8:681252.

Ou, L., Lundgren, V., Lu, S. \& Granéli, E. 2014. The effect of riverine dissolved organic matter and other nitrogen forms on the growth and physiology of the dinoflagellate Prorocentrum minimum (Pavillard) Schiller. J. Sea Res. 85:499-507.

Park, S. A., Jeong, H. J., Ok, J. H., Kang, H. C., You, J. H., Eom, S. H. \& Park, E. C. 2021. Interactions between the kleptoplastidic dinoflagellate Shimiella gracilenta and several common heterotrophic protists. Front. Mar. Sci. 8:738547.

Peterson, D. H. \& Festa, J. F. 1984. Numerical simulation of phytoplankton productivity in partially mixed estuaries. Estuar. Coast. Shelf Sci. 19:563-589.

Raven, J. A., Beardall, J., Flynn, K. J. \& Maberly, S. C. 2009. Phagotrophy in the origins of photosynthesis in eukaryotes and as a complementary mode of nutrition in phototrophs: relation to Darwin's insectivorous plants. J. Exp. Bot. 60:3975-3987.

Schnepf, E. 1992. From prey via endosymbiont to plastid: comparative studies in dinoflagellates. In Lewin, R. A. (Ed.) Origins of Plastids: Symbiogenesis, Prochlorophytes, and the Origins of Chloroplasts. Springer, Boston, MA, pp. 53-76.

Schnepf, E. \& Elbrächter, M. 1992. Nutritional strategies in dinoflagellates: a review with emphasis on cell biological aspects. Eur. J. Protistol. 28:3-24.

Schnepf, E. \& Elbrächter, M. 1999. Dinophyte chloroplasts and phylogeny: a review. Grana 38:81-97.

Sellers, C. G., Gast, R. J. \& Sanders, R. W. 2014. Selective feeding and foreign plastid retention in an antarctic dinoflagellate. J. Phycol. 50:1081-1088.

Skovgaard, A. 1998. Role of chloroplast retention in a marine dinoflagellate. Aquat. Microb. Ecol. 15:293-301.

Smalley, G. W. \& Coats, D. W. 2002. Ecology of the red-tide dinoflagellate Ceratium furca: distribution, mixotrophy, and grazing impact on ciliate populations of Chesapeake Bay. J. Eukaryot. Microbiol. 49:63-73.

Smayda, T. J. \& Reynolds, C. S. 2003. Strategies of marine dinoflagellate survival and some rules of assembly. J. Sea Res. 49:95-106.
Stat, M., Morris, E. \& Gates, R. D. 2008. Functional diversity in coral-dinoflagellate symbiosis. Proc. Natl. Acad. Sci. U. S. A. 105:9256-9261.

Stoecker, D. K., Hansen, P. J., Caron, D. A. \& Mitra, A. 2017. Mixotrophy in the marine plankton. Annu. Rev. Mar. Sci. 9:311-335.

Strathmann, R. R. 1967. Estimating the organic carbon content of phytoplankton from cell volume or plasma volume. Limnol. Oceanogr. 12:411-418.

Tamura, K., Dudley, J., Nei, M. \& Kumar, S. 2007. MEGA4: molecular evolutionary genetics analysis (MEGA) software version 4.0. Mol. Biol. Evol. 24:1596-1599.

Taylor, F. J. R., Hoppenrath, M. \& Saldarriaga, J. F. 2008. Dinoflagellate diversity and distribution. Biodivers. Conserv. 17:407-418.

Tillmann, U. \& Reckermann, M. 2002. Dinoflagellate grazing on the raphidophyte Fibrocapsa japonica. Aquat. Microb. Ecol. 26:247-257.

Unrein, F., Gasol, J. M., Not, F., Forn, I. \& Massana, R. 2014. Mixotrophic haptophytes are key bacterial grazers in oligotrophic coastal waters. ISME J. 8:164-176.

Verity, P. G., Stoecker, D. K., Sieracki, M. E., Burkill, P. H., Edwards, E. S. \& Tronzo, C. R. 1993. Abundance, biomass and distribution of heterotrophic dinoflagellates during the North Atlantic spring bloom. Deep Sea Res. II Top. Stud. Oceanogr. 40:227-244.

Yang, H., Hu, Z., Shang, L., Deng, Y. \& Tang, Y. Z. 2020. A strain of the toxic dinoflagellate Karlodinium veneficum isolated from the East China Sea is an omnivorous phagotroph. Harmful Algae 93:101775.

Yoo, Y. D., Jeong, H. J., Kang, N. S., Song, J. Y., Kim, K. Y., Lee, G. \& Kim, J. 2010. Feeding by the newly described mixotrophic dinoflagellate Paragymnodinium shiwhaense: feeding mechanism, prey species, and effect of prey concentration. J. Eukaryot. Microbiol. 57:145-158.

Yoo, Y. D., Jeong, H. J., Kim, J. S., Kim, T. H., Kim, J. H., Seong, K. A., Lee, S. H., Kang, N. S., Park, J. W., Park, J., Yoon, E. Y. \& Yih, W. H. 2013. Red tides in Masan Bay, Korea in 2004-2005: II. Daily variations in the abundance of heterotrophic protists and their grazing impact on red-tide organisms. Harmful Algae 30(Suppl. 1):S89-S101.

You, J. H., Jeong, H. J., Kang, H. C., Ok, J. H., Park, S. A., \& Lim, A. S. 2020. Feeding by common heterotrophic protist predators on seven Prorocentrum species. Algae 35:61-78.

Zhang, Q., Yu, R., Song, J., Yan, T., Wang, Y. \& Zhou, M. 2011. Will harmful dinoflagellate Karenia mikimotoi grow phagotrophically? Chin. J. Oceanol. Limnol. 29:849-859. 